\title{
Bağımsız Denetime İlişkin Düzenlemeler ve Bu Düzenlemelerin Etkileri Üzerine Bir Araştırma: Kayseri Ve Sivas İli Örneği ${ }^{1}$
}

\author{
Seval ELDEN ÜRGÜP
}

Dr. Öğr. Üyesi, Sivas Cumhuriyet Üniversitesi, İktisadi ve İdari Bilimler Fakültesi, İşletme Bölümü sevalelden@hotmail.com

Orcid ID: https://orcid.org/0000-0002-7464-3485

\author{
Rahime Merve BAŞAR \\ Yüksek Lisans Öğrencisi, Sivas Cumhuriyet Üniversitesi, \\ Sosyal Bilimler Enstitüsü, İşletme Ana Bilim Dalı \\ mervebasar123@gmail.com \\ Orcid ID: https://orcid.org/0000-0002-2121-6041
}

\begin{abstract}
$\ddot{\mathbf{O} z}$
$\mathrm{Bu}$ çalı̧̧manın amacı; ülkemizde birçok sorunla karşılaşan ve düzene oturtulamayan bağımsız denetim kavramının 6102 sayılı Yeni Türk Ticaret Kanunu'nun yayınlanması ile birlikte yeniden düzenlenmesinin bağımsız denetime etkilerini, bağımsız denetimin önemini, kalitesini, sağladığı faydaları ve bağımsız denetçileri nasıl etkilediğini ortaya koymaktır. Çalışma kapsamında, Ertaş (2018) tarafindan geliştirilen ve veri toplama aracı olarak kullanılan anket formu TR 72 bölgesinde faaliyet gösteren bağımsız denetim kuruluşlarına bağlı 63 bağımsız denetçiye uygulanmıştır. Elde edilen veriler üzerinden frekans, yüzde, ortalama ve standart sapma hesaplanmış ayrıca Ki-Kare Bağımsızlık Testi kullanılarak analiz edilmiştir. Verilerin analizi sonucunda; yapılan denetim kapsamının işletme yönetimi tarafından bilinmediği, denetim firmaları arasında yüksek bir rekabetin olduğu, bağımsız denetim kapsamında verilen mesleki eğitim ve yeterliliğe yeteri kadar önemin verilmediği belirlenmiştir. Ayrıca, denetime ilişkin düzensizliklerin var olduğu ve diğer mevzuat hükümleri ile denetim standartlarının birbiri ile uyum içinde olmadığı, uyumlu hale getirilmesi gerektiği tespit edilmiştir.
\end{abstract}

Anahtar Kelimeler: Bağımsız Denetim, Bağımsız Denetçi, 6102 Sayılı Yeni TTK.

\footnotetext{
${ }^{1}$ Makale Geliş/Kabul Tarihi: 20.05.2021/15.11.2021

Künye Bilgisi: Elden Ürgüp, S. ve Başar, R.M. (2021). Bağımsız denetime ilişkin düzenlemeler ve bu düzenlemelerin etkileri üzerine bir araştırma: Kayseri ve Sivas ili örneği. Kahramanmaraşs Sütçü Imam Üniversitesi Sosyal Bilimler Dergisi, 18 (3), 22512280. DOI: $10.33437 / \mathrm{ksusbd} .923387$.
} 


\title{
A Research on TheRegulations Related to Independent Audit and The Effects of These Regulations: The Case of Kayseri And Sivas City
}

\begin{abstract}
The aim of this study is; To reveal the effects of the reorganization of the concept of independent audit, which is faced with many problems in our country and could not be regulated, on independent auditing with the publication of the New Turkish Commercial Code numbered 6102, the importance of independent auditing, its quality, benefits and how it affects independent auditors. Within the scope of the study, the questionnaire form developed by Ertas (2018) and used as a data collection tool was applied to 63 independent auditors affiliated with independent audit institutions operating in the TR 72 region. Frequency, percentage, mean and standard deviation were calculated from the data obtained and analyzed using the Chi-Square Test of Independence. As a result of the analysis of the data; It has been determined that the scope of the audit performed is not known by the business management, there is a high competition among audit firms, and that sufficient attention is not given to the professional training and competence given within the scope of independent audit. In addition, it has been determined that there are irregularities regarding the audit and that other legislative provisions and audit standards are not in harmony with each other and they need to be harmonized.
\end{abstract}

Keywords: Independent Auditing, Independent Auditor, 6102 Numbered Turkish Commercial Code.

\section{GİRIŞ}

Finansal tabloların güvenilir, şeffaf ve doğru olup olmadıklarını tarafsız bir biçimde belirleyen ve bunu rapor ederek bilgi kullanıcılarına sunulmasını sağlayan süreç bağımsız denetimdir. Bağımsız denetim süreci, finansal tabloların genel kabul görmüş muhasebe ilkelerine uyumlu ve yasal düzenlemelere uygun şekilde oluşturulup oluşturulmadığına dair bir görüş bildirilmesidir. Finansal tabloların doğruluğunu araştırmak denetimin ilk amacıdır(Kaya, 2020: 336).

1957 yılında yürürlüğe giren 6762 sayılı kanunla tüm dünyada yaşanan ticari gelişmelere karşın mevcut ihtiyaçlar karşılanamamış ve kanun yetersiz kalmıştır. 50 yıldan fazla süredir kullanılan kanunda hiçbir güncelleme yapılmaması eksiklikler doğurmuştur(Karakoç, 2013: 18). 6762 say1l kanunda şirketlerin bağımsız denetiminden bahsedilmemiştir. Ticari işletmelerin denetimi, şirketin üç kanuni organından biri olan ve uzmanlık bilgisinin gerekli olmadığı murakıplar aracılı̆̆ıyla yapılmasından bahsedilmiştir. Denetçilerde herhangi bir 


\section{S.Elden Ürgüp-R.M. Bașar Bă̆ımsız Denetime İliskin Düzenlemeler...}

uzmanlık bilgisinin aranmaması, denetçileri şirketin diğer organlarının seçmesi ve yöneticiler ile denetçiler arasında oluşan menfaat ilişkisi şirketlerin denetimi konusunda yeni düzenlemelerin yapılmasına zemin hazırlayan etkenlerdir. Aynı zamanda 2000'li yılların başlarında ortaya çıkan Enron skandalı, Parmalat vakası ve Worlcom olayı bağımsız denetim konusunun birçok ülkede yeniden ele alınması gerektiğini göstermiştir (Bulut, 2015: 64). Diğer taraftan, Türkiye'nin Avrupa Birliği uyum süreci sebebiyle ulusal ve uluslararası ticari hayat1 kolaylaştırıcı yeni hükümler getirmesi gerekmiştir. Finans ve sermaye piyasalarıyla ilgili düzenlemelerin yapılması ve bunların da dışında finansal raporlama sürecinde şeffaflık gibi güncel ve genel kabul görmüş standartları içeren yeni bir kanunun oluşturulması şart olmuştur (Ulusan vd, 2012:12).

Sermaye Piyasası Kanunu, Bankacılık Kanunu, Sigortacılık Kanunu ve Enerji Piyasası Kanunu çerçevesinde çıkarılan yeni yönetmelikler ile bağımsız denetime ilişkin düzenlemeler yapılmış ve bağımsız denetim her bir kurumun sorumlu olduğu yapı içerisinde yapılması zorunlu kılınmıştır. Bu durum ise bağımsız denetim konusunda dağınıklığa yol açmış, genel düzenlemeler ve standart belirlemelerde sorunlar ortaya çıkarmıştır. Bu durumların önüne geçmek için yeni kanun düzenlemeleri ile bağımsı denetime dair genel standartlarbenimsenmiştir(Bulut, 2015:65).

Yürürlüğe giren 6102 sayılı Yeni Türk Ticaret Kanunu (YTTK) kamuyu aydınlatma ve şeffaflık ilkeleri kapsamında birçok yenilik getirmiştir. YTTK ile birlikte temel ticari işlemler, muhasebeleştirme, kayıt düzeni ve değerleme işlemleri yeniden ele alınmıştır. Türk şirketlerinin kurumsallaşması, sürdürülebilirliği, rekabet gücünün artması, kamu güveninin oluşturulması ve şeffaflık gibi önemli fayda ve katkılar sunmuştur (Özulucanvd, 2015:27). Bu bilgiler çerçevesinde bağımsız denetim ile ilgili yapılan yasal düzenlemelerin denetim sürecine, denetimin güvenilirliğine ve kalitesine, denetlenen şirketlere ve bağımsız denetimde bulunan muhasebe meslek mensuplarına ne gibi etkilerinin olduğu araştırılmıştır. Bağımsız denetçilerin, yapılan yasal düzenlemeler hakkındaki görüşleri ve farlındalıkları tespit edilmeye çalışılmıştır.

\section{BAĞIMSIZ DENETIMM KAVRAMI}

Bağımsız denetim kavramını açıklamadan önce daha genel çerçeveye sahip denetim kavramının açıklanması daha doğru olacaktır. Bu doğrultuda denetim kavramı bağımsız denetim kavramını da içinde barındırmaktadır. Denetim kavramının birçok farklı tanımı yapılmış olsa da en yaygın kabul edilen tanımı Amerika Muhasebeciler Birliği Temel Denetim Kavramları Komitesi yapmıştır ve şu şekilde açıklamıştır: "Denetim, iktisadi faaliyet ve olaylarla ilgili iddiaların (sonuçların) önceden saptanmış ölçütlere uygunluk derecesini araştırmak ve sonuçlart ilgi duyanlara bildirmek amactyla tarafsızca kanıt toplayan ve bu 
kanıtları değerleyen sistematik bir süreçtir" (Karadeniz, 2015:314). Bağımsız Denetim Yönetmeliği'nde tanımlar bölümünün $b$ bendinde bağımsız denetim şöyle tanımlanmıştır: "Finansal tablorın, finansal bilgilerin, finansal raporlama standartlarına uygunluğu ve doğruluğu hususunda, makul güvence sağlayacak yeterli ve uygun bağımsız denetim kanitlarının elde edilmesi amacıyla, denetim standartlarında öngörülen gerekli bağımsız denetim tekniklerinin uygulanarak defter, kaylt ve belgeler üzerinden denetlenmesi ve değerlendirilerek raporlanmasını" ifade eder. Kısaca tanımlayacak olursak bağımsız denetim mali tabloların güvenilir ve doğru olup olmadıklarını tarafsız bir biçimde belirleyen ve bunu rapor eden faaliyettir. Şunu belirtmek gerekir ki bu denetimin asıl amac1 ortaklıklar ve sermaye piyasası kurumlarına ait hesapların vergi kanunları açısından incelenmesi değildir. Asıl amaç, kamuoyuna açıklanan veya açılanacak olan mali tabloların uluslararası muhasebe ilke ve standartlarına uygunluğunun incelenmesidir (Erdoğan, 2002:59).

Yapmış olduğumuz tanımlardan da yola çıkarak bazı kaynaklarda muhasebe denetimi olarak bahsedilen bağımsız denetimin temel özelliklerinden şu şekilde bahsedebiliriz (Demirtaş Aydoğan, 2016: 772):

- Bağımsız denetim iktisadi bir işletmenin belli bir dönemini kapsamalıdır.

- Denetlenen bilgiler ile önceden belirlenmiş ölçütler karşılaştırılır.

- Denetçi bağımsız olarak tarafsız bir şekilde çalışmalarını yürütmelidir.

- Denetçi yeterli düzeyde mesleki bilgi ve tecrübeye sahip olmalıdır.

- Denetçi uygun teknikleri kullanarak yeterli düzeyde kanıt toplar ve bu kanıtları birleştirir ve sonuçta denetçi işletme ile ilgilenenler için işletmenin durumunu tarafsızca belirttiği bir rapor sunar.

\section{BAĞIMSIZ DENETIMIN ÖNEMİ VE FAYDALARI}

Finansal tablo ve finansal verileri hazırlayan işletme ile bu veri ve tablolardan faydalanacak olan işletme diş çevresi yani ortaklar, yöneticiler, işletmeye borç verenler, devlet, tüketiciler ve yatırımcılar arasında bir çıkar çatışması sebebiyle bilgilerin güvenilir olma derecesi artmıştır. İşletmenin sahip olduğu finansal verilerin, muhasebe bilgi ve belgelerin çok ve karmaşı olması, diş çevrenin bu verilere ulaşmakta güçlük çekmesi güvenilirliği azaltan etkenler arasındadır. $\mathrm{Bu}$ noktada güvenilir ve doğru bilgilerin işletme dış çevresinde kullanılacağ için fazlasıyla önem taşımaktadır. İşletme ve dış çevre arasında güvenli bilgi ve belgelerin sağlanabilmesi için yönetime bağlı olmayan bağımsız denetim şarttır (Ertaş, 2018:17).

Bağımsız denetim, işletmelerin özellikle finansal tablolarında daha şeffaf davranmalarını, işletme içinde kurumsal yönetim ilkelerinin daha uygun şekilde yapılmasını sağlar. Etkili bir bağımsız denetim süreci ile orta vadede işletmelerin güvenilir olma seviyesi artacaktır. Devletin denetim yapması kolaylaşacaktır. 


\section{S.Elden Ürgüp-R.M. Bașar Bă̆ımsız Denetime İliskin Düzenlemeler...}

Kredi kuruluşlarının ve yabancı ülkelerin yerli işletmelere olan güveni artacak özellikle de finansal tablolar daha şeffaf ve güvenilir olacaktır. Bu sebeple ülkemize yapılan yatırımlar artacak ve ekonomik kalkınma açısından önemli gelişmeler yaşanabilecektir(Karadeniz, 2015:317).

\section{TÜRKIYY'DE BAĞIMSIZ DENETIMIN TARIHHSEL GELIŞIMI}

1839 y1lında Türk muhasebe sistemi ile Avrupa'nın muhasebe sistemini bütünleştirme uğraşları Tanzimat'la birlikle gelen bazı reformlarla başlamış fakat muhasebe mesleğine zemin hazırlayan asıl yasal düzenlemeler 1989 yılında yapılmıştır. Bu durum da dolayısıyla Türk muhasebe kültürünün fiili ve hukuki tarihinin eş zamanlı ilerlememesine sebep olmuştur(Uzay ve Bayat, 2016:1504).

Muhasebe denetimi, Osmanlı İmparatorluğunda mali işlemlerin düzenlenmesi yani devletin gelirlerinin ve giderlerinin incelenmesi ve izlenmesi için kullanılmıştır. Türkiye'de cumhuriyetin ilanıyla birlikte muhasebe denetimi 1926 ve 1934 yılları arasında gelişim göstermiş ve bu yıllarda mahkemelerde bilirkişilik faaliyetleri başlangıç kabul edilmektedir (Doğan ve Hilal, 2019: 24). 1926-1934 yılları arasında mesleğinde dürüstlüğü ile tanınan kişilere denetleme yetkisi verilmiştir. 1942'de ise muhasebe mesleğinin örgütlenme ihtiyac1 ile Türkiye Muhasebe Uzmanları Derneği kurulmuştur. 1970'li yıllarda denetim alanında ilk gelişmeler yaşanırken modern anlamda ilk gelişmeler ise 1990'lı yılları bulmuştur (Aydın ve Deniz, 2018:2485).

1927 yılında çıkarılan İşletme Vergisi Kanunu Türkiye Cumhuriyeti tarihinin ilk bağımsız denetim ile ilgili düzenlemesi olarak kabul edilir. 1942 yılında denetim ve muhasebe alanındaki meslek sahiplerinin örgütlenebilmesi için Türkiye Muhasebe Uzmanları Derneği kurularak önemli bir adım atılmıştır(Ertaş, 2018: 25). İlk olarak 1960'lı yıllarda bağımsız denetim uygulamaları banka ve diğer finansal kurumların istekleri üzerine başlamıştır. 1985'te İMKB'nin kurulması ve 1987 yılında yapılan düzenlemeler ile birlikte bankacılık sektöründe ilk zorunlu bağımsız denetim uygulamaları başlamıştır. Bu düzenlemelerden hemen sonra aynı yıl Sermaye Piyasası Kuruluna tabi şirketler için de zorunlu bağımsız denetim uygulamaları getirilmiştir. Bağımsız denetim uygulamalarının ilke ve kuralları ilk 1988 yılında Sermaye Piyasası Kurulu tarafindan yayımlanan tebliğler ile belirlenmiştir (Uzay ve Bayat, 2016:1505). 1989 yılında resmi gazetede yayımlanan 3568 sayıli Serbest Muhasebecilik, Serbest Muhasebeci Mali Müşavirlik ve Yeminli Mali Müşavirlik Kanunu ile birlikte Türkiye Serbest Muhasebeci Mali Müşavirler ve Yeminli Mali Müşavirler Odaları Birliği(TÜRMOB) yasal statüye sahip olmuştur. Türkiye'de muhasebe ilkelerinde tekdüzen sistemini oluşturmak ve faaliyette olan işletmelerin finansal tablolarının düzenlenmesini esas almak amacıyla 1994'te TÜRMOB bünyesinde Türkiye Muhasebe ve Denetim Standartları Kurulu (TMÜDESK) kurulmuştur. 
TMÜDESK 19 adet standart yayımlamıştır. Fakat TMÜDESK tarafindan yayımlanan standartlar yasal yaptırım gücü olmaması sebebiyle uygulanamamış ve tavsiye niteliğinde kalmıştır (Bezirci ve Karasioğlu: 578-580). 2002 yılında TMÜDESK'in görevlerini Türkiye Muhasebe Standartları Kurulu(TMSK) devralmıştır. Muhasebe standartlarının belirlenmesi kapsamında tek yetkili kuruluş olmuştur. 2005 yılında Avrupa Birliği'ne tam üyelik sürecinin başlaması ile birlikte tüm mevzuatın Avrupa Birliği müktesebatı ile uyumlu olma zorunluluğu oluşmuştur. Bu sebeple, Adalet Bakanlığı'na bağlı bir komisyon kurulmuş ve bu komisyon 2007 yılında yeni Türk Ticaret Kanunu Taslağını hazırlaması için görevlendirilmiştir. Bu yeni Türk Ticaret Kanunu'nda TMSK'nın yetkilerinden ve Türkiye Muhasebe Standartları'ndan (TMS) bahsedilmiştir. Yayımlanan bu TMS'leri 2005 yılından itibaren SPK mevzuatına tabi borsada işlem gören şirketlere uygulama zorunluluğu getirilmiştir (Yünlü, 2020:185). Bağımsız denetimin düzenlendiği 6102 sayılı yeni Türk Ticaret Kanunu 2011 yılında yayımlanmıştır. 660 Sayılı Kanun Hükmünde Kararname ile denetim uygulamalarını düzenlemek için Kamu Gözetimi, Muhasebe ve Denetim Standartları Kurumu(KGK) kurulmuştur. Bu kurum bağımsız denetim standartları ve esasları, bağımsız denetçi olma şartları gibi çeşitli alanları düzenlemekle ve denetimi şekillendirme ile görevli yetkili kurum olmuştur (Ertaş, 2018:27).

\section{TÜRKIYE'DE DENETIM ILLE ILGILI ÇALIŞMALARI YÜRÜTEN KURULUŞLAR}

Türkiye'de bağımsız denetimin gelişimi, çeşitli kurum ve kuruluşların kendi bünyelerinde tek düzeni sağlamak amacıyla ve zaman içinde AB'ye tam üyelik başvurusu ve $\mathrm{AB}$ ile uyum sürecinin etkisi ile yeni düzenlemelere gidilmiştir.

Türkiye'de bağımsız denetim çalışmalarına ilişkin düzenlemeler genel olarak aşağıda başlıklar halinde verilmiştir.

\section{Kamu Gözetimi Kurumu ve Bağımsız Denetim}

Kamu Gözetimi Muhasebe ve Denetim Standartları Kurumu 26.09.2011 yılında yayımlanan 660 sayılı KHK ile kurulmuştur (660 sayılı KHK, 2011:1279). Denetim 1987 yılından beri farklı kurumlar tarafindan yapılıyordu. Bağımsız denetçi ve denetim kuruluşlarının denetimini tek bir elden yürütmek adına ve uygulamalardaki farklılıkların, eksikliklerin ortadan kaldırılması amacıyla KGK kurulmuştur(Aydın ve Deniz, 2018: 2488). AB 8 nolu direktifi ve yeni TTK ile dağınık yapının sistematik bir hale gelmesi zorunlu kılınmıştır. $\mathrm{Bu}$ doğrultuda KGK'nın neden kurulduğuna dair gerekçelere bakacak olursak; uygulamada tek bir otorite sağlamak, AB 8 nolu direktifine uyum sağlamak, denetimde kaliteli ve güvenilir olmayı sağlamak, mali tablolarda tek tip düzenleme ve denetim standartlarını uygulamak, uluslararası gelişimlere ayak 


\section{S.Elden Ürgüp-R.M. Bașar Bă̆ımsız Denetime İliskin Düzenlemeler...}

uydurabilmek için bunlara uyumlu ulusal standartlar oluşturmak ve şeffaf bir sermaye piyasası oluşturmak (Fırat ve Şahin,2012 :6).

660 sayılı KHK'nin 9. maddesinde kurumun yetki ve görevleri belirtilmiştir. KGK'nın temel amacı yatırımcıların çıkarlarını korumak ve oluşturulan denetim raporlarının bağımsız, doğru ve şeffaf şekilde hazırlanmasını sağlayarak kullanıcılara güvenilir ve karşılaştırılabilir finansal bilgi sunumunu sağlamaktır. Diğer kuruluş amaçları ise şu şekilde sıralanabilir; Türkiye Muhasebe Standartlarını oluşturmak ve yayımlamak, Ulusal Denetim Standartlarını oluşturmak ve yayımlamak, uygulamalarda tek otoriteyi sağlayarak gerekli olan güven ve kaliteyi oluşturmak, bağımsız denetçilere ve bağımsız denetim kuruluşlarına yetki vermek ve yaptıkları faaliyetleri denetlemek, gerektiği gibi denetleme yapmayan denetçi ve kuruluşların faaliyet izinlerini iptal etmek veya askıya almak (Ertaş, 2018:28).

\section{Türkiye Sermaye Piyasasında Bağımsız Denetim}

Sermaye Piyasası Kurulu 2499 sayılı yasa ile kurulmuş olup bağımsız denetime dair ilk düzenlemesini 1987 yılında yürürlüğe giren Bağımsız Denetim Yönetmeliği ile yapmıştır. Ülkemizde bağımsız denetimin yasal zemine oturtulması ve bu konudaki ilk mevzuat düzenlemesi olması açısından bu yönetmelik önem teşkil etmektedir (Firat ve Şahin, 2012:2). Daha sonra ise amac1 "Sermaye piyasasında bağımsız denetim faaliyetine, bu faaliyette bulunmak üzere kurulca yetkilendirilecek bağımsız denetim kuruluşlarına ve bağımsız denetçilere ilişkin standart, ilke, usul ve esasları belirlemek" olan Sermaye Piyasasında Bağımsız Denetim Standartları Hakkında Tebliğ yayımlanmıştır (https://spk.gov.tr).

Bağımsız denetçiler, müşteriler ve üçüncü kişiler arasında oluşan fikir ayrılıkları ve bu sebeple oluşan denetim faaliyetlerinin ilke ve kurallara uygun yapılmaması durumu önemli zararlar doğurur. Bu noktada bağımsız denetim şirketlerinin idari, hukuki ve cezai sorumlulukları SPK tarafindan düzenlenmektedir(Akyüz ve Kestane, 2020:197). Sermaye piyasasında bağımsız denetim şu şirketler için zorunluluk arz etmektedir; halka açık şirketler, aracı kurumlar, bankalar, menkul kıymet yatırım ortaklıkları, menkul kıymet yatırım fonları, sigorta şirketleri, gayrimenkul yatırım ortaklıkları ve faktoringşirketler (Çelik, 2012:80). Ayrıca, bağımsız denetim kuruluşlarının yetkilendirilmesinde ek şartları belirleme yetkisi, bağımsız denetim kuruluşlarını liste halinde ilan etme yetkisi, kalite kontrol ve denetim çalışmaları yapma yetkileri SPK'ya verilen yetkiler arasındadır (https://www.mevzuat.gov.tr). 


\section{BDDK Açısından Bağımsız Denetim}

1999 yılında 4389 sayılı Bankalar Kanunu'yla Bankacılık Düzenleme ve Denetleme Kurumu (BDDK) kurulmuş ve sonrasında 2005 yılında yeniden hazırlanarak yürürlüğe girmiştir. Bankalar Kanunu'nda BDDK'nın görevleri şu şekilde belirtilmiştir; "Finansal piyasalarda güven ve istikrarın sağlanmasina, kredi sisteminin etkin bir şekilde çalışmasına, tasarruf sahiplerinin hak ve menfaatlerinin korunmasına ilişkin usul ve esasları düzenlemek" (Güvemli ve Özbirecikli, 2011:164).

Bağımsız Denetim ile ilgili BDDK'nın yetkileri şu şekildedir; denetim kuruluşlarına ilave şartlar getirme yetkisi, denetim kuruluşlarını listeler halinde açıklama yetkisi, denetim faaliyetleri ile ilgili denetim çalışmaları ve kalite kontrol işlemlerini yapma yetkisi, mevzuata veya standartlara uymayan şirketleri geçici veya sürekli olarak listeden çıkarma yetkisi, yapılan kalite kontrol ve denetim çalışması sonuçlarının KGK'ya bildirilmesi yetkisi (https://www.mevzuat.gov.tr).

\section{Enerji Piyasası Düzenleme Kurumu ve Bağımsız Denetim}

İlk olarak 4628 sayılı kanun ile Elektrik Piyasası Düzenleme Kurulu olarak kurulmuş olan bu kurul daha sonra 4646 sayılı Doğal Gaz Piyasası Kanunu ile Enerji Piyasası Düzenleme Kurumu adını almıştır. Bu kuruma, 5015 sayılı Petrol Piyasası Kanunu ile petrol piyasasını düzenleme ve denetleme yetkileri verilmiştir. Daha sonra ise yine aynı yetki, 5307 sayılı Sıvılaştııılmış Petrol Gazları Piyasası Kanunu ile sıvılaştııılmış petrol gazları(LPG) için verilmiştir. 2001 tarihi ile de Enerji Piyasası Düzenleme Kurulu görevine başlamıştır (www.epdk.gov.tr).

Çıkarılan bu kanunların amacı ise; elektrik, doğal gaz, petrol ve LPG'nin kaliteli, yeterli, sürekli, düşük maliyetli ve çevre ile uyumlu bir biçimde tüketicilerin kullanımına sunulurken, rekabet içerisinde özel hukuk hükümlerine göre faaliyet gösterebilen, mali yönden güçlü, istikrarlı ve şeffaf bir enerji piyasası oluşturmak ve bu piyasada bağımsız bir düzenleme ve denetim işlemlerinin gerçekleşmesini sağlamaktır (www.epdk.gov.tr).

\section{Yeni Türk Ticaret Kanunu'nda Bağımsız Denetim}

6102 sayılı Türk Ticaret Kanunu 14 Şubat 2011 y1lında kabul edilerek Resmi Gazete'de yayımlanmış ve 1 Temmuz 2012 y1lında ise yürürlüğe girmiştir. Yürürlüğe giren Yeni Türk Ticaret Kanunu(YTTK) kamuyu aydınlatma ve şeffaflık ilkeleri kapsamında birçok yenilik getirmiştir. YTTK ile birlikte temel ticari işlemler, muhasebeleştirme, kayıt düzeni ve değerleme işlemleri yeniden ele alınmıştır. Türk şirketlerinin kurumsallaşması, sürdürülebilirliği, rekabet 


\section{S.Elden Ürgüp-R.M. Bașar Bă̆ımsız Denetime İliskin Düzenlemeler...}

gücünün artması, kamu güveninin oluşturulması ve şeffaflık gibi önemli fayda ve katk1lar sunmuştur (Özulucan vd, 2015: 27).

YTTK, tüm şirketlerin muhasebe ve finansal raporlama konularında Uluslararası Finansal Raporlama Standartlarına uyumlu Türkiye Finansal Raporlama Standartlarına uyma zorunluluğu getirmiştir. Artık şirketlerin finansal tablolarının denetimleri bu standartlara göre yapılacaktır. Yönetim kurulunun sunduğu finansal bilgilerin, denetlenen finansal tablolar ile tutarlı olup olmadığ 1 ve gerçeği ne kadar yansıttığı denetim kapsamı içine alınmıştır. Tüm sanayileşmiş ülkeler ile aynı finansal raporlama standartlarının kullanımı işletmelerin uluslararası piyasada rekabet gücü elde etmesini sağlayacaktır (Demir vd, 2016:42).

6102 sayılı YTTK; defterler ve belgeler ile ilgili, envanter ve değerleme ile ilgili, muhasebe standartlarını uygulama yükümlülüğü ile ilgili ve bağımsız denetim ile ilgili yenilikler getirmiştir. Defter tutma konusunda gerçek ve tüzel kişi ayrımı ortadan kaldırılmış ve tüm tacirler için yevmiye defteri, defteri kebir ve envanter defteri tutulması öngörülmüştür. Pay defteri, yönetim kurulu karar defteri ve genel kurul toplantı defteri de ticari defter olarak vurgulanmıştır. YTTK ile birlikte TFRS'ye uygun olması şartıyla defterler fiziki olarak saklanabileceği gibi elektronik ortamda da saklanabilecektir(Ulusan vd, 2012: 14). Denetçi, bağımsız denetim yapmak üzere ruhsat almış yeminli mali müşavir veya serbest muhasebeci mali müşavir unvanını taşıyan ve KGK tarafından görevlendirilmiş kişiler veya ortakları ve bu kişilerden oluşan sermaye şirketi olabilir(Özçelik vd, 2014: 57). YTTK ile birlikte önceden murakıp olarak seçilebilen pay sahipleri artık bağımsız denetçi olamamaktadır. Ayrıca denetçinin bağımsız olmasını sağlayabilmek için bir bağımsız denetleme kuruluşu tarafından görevlendirilen denetçi yedi yıl arka arkaya aynı şirket için denetleme raporu vermişse o denetçinin en az üç yıl için değiştirilmesi istenmektedir. Bunlara ek olarak, denetçinin denetleme yaptığ 1 şirkete vergi danışmanlığı ve vergi denetimi dışında danışmanlık veya hizmet vermesi ve bunu bir yavru şirketi aracılı̆̆ıyla yapması yasaktır (Ulusan vd, 2012:19).

$\mathrm{Bu}$ bilgiler doğrultusunda 6102 sayılı YTTK tarafından getirilen en önemli yenilikler şirket denetimlerinin YMM ve SMMM'ye bırakılmas1 ve denetimde UFRS ile uyumlu TFRS'nın uygulanması olmuştur. Denetim tamamen bağımsız denetçilere bırakılmış ve denetçiler şirket organı olmaktan çıkarılmıştır(Fırat ve Şahin:5-6).

\section{LITERATÜR TARAMASI}

Bağımsız denetimin gelişim süreci ve yasal düzenlemelerin bağımsız denetime etkileri incelendiğinde bu konu üzerine çeşitli çalışmaların yapıldığ görülmektedir. 
Ulusan vd. (2012) çalışmalarında, 6102 sayılı Yeni TTK'nın muhasebe ve denetim uygulamalarına getirmiş olduğu yenilikler hakkında muhasebe meslek mensuplarının görüşlerinin alınması ve bu görüşlerin hem eğitim seviyeleri bakımından hem de meslekteki çalışma yılları açısından farklılık gösterip göstermediğinin araştırılmasını amaçlamışlardır. Yozgat il merkezinde faaliyet gösteren 45 meslek mensubu üzerinden yapılan çalışmada; verilerin analizinde aritmetik ortalama, tek tönlü varyans analizi, frekans analizi ve Tukey testi kullanılmıştır. Çalışma sonucunda; muhasebe meslek mensuplarının görüşlerinin alınmasıyla 6102 sayılı Yeni TTK'nın muhasebe ve denetim uygulamalarına getirmiş olduğu yeniliklerin doğru ve gerekli veya yeterli olduğu görüşü ortaya çıkmıştır.

Karakoç (2013) 6102 sayılı yeni TTK ile bağımsız denetimde oluşan gelişmeleri ele almıştır. İki bölümden oluşan çalışmanın ilk bölümünde Yeni TTK'nın bağımsız denetim ile ilgili maddeleri incelenmiş ve bu maddelere yapılan eleştirilere ve bazı görüşlere yer verilmiştir. İkinci bölümde ise yapılan düzenlemeler ile birlikte bağımsız denetçiler ve bağımsız denetim eğitimleri hakkında bilgiler bulunmaktadır. Çalışmanın sonucu olarak; KGK'nın bağımsız denetim alanında çatı görevi görmesi gerektiği, kuruma düşen görev ve yetkilerin büyük önem arz ettiği ve bağımsız denetim konusunda eğitim veren kurumlara büyük sorumluluklar düşerek bağımsız denetim mekanizmasının sağlıklı işlemesinin sağlanması gerektiği sonucuna varılmıştır.

Özçelik vd. (2014) çalışmalarında, Antalya, Isparta ve Burdur illerinde faaliyet gösteren muhasebe meslek mensuplarının bağımsız denetim alanında gerçekleşen yeniliklere bakış açılarını ve farkındalıklarını ortaya koymayı amaçlamışlardır. Bu amaçla yürütülen anket çalışmasında, araştırma kapsamına giren toplam 2279 muhasebe meslek mensubundan 750'sine ulaşılmış ve bunlardan da 393 'ünden cevap alınmıştır. Araştırma sonucunda; muhasebe meslek mensuplarının yarıya yakınının bağımsız denetçi olmayı düşündüğü, bağımsız denetim ve uygulamaları ile ilgili bilgi düzeylerinin düşük olduğu ve bağımsız denetim alanındaki kuruluşların uyumlu çalışma sistemleri ile başarının yakalanacağı tespit edilmiştir.

Karadeniz (2015) çalışmasında, 6102 sayılı Yeni TTK ile yeni bir boyut kazanan kurumsal yönetim uygulamalarını açıklamayı ve ülkemizde birçok sorunla karşılaşıp düzene oturtulamayan bağımsız denetimin önemini, şu an ki ve gelecekteki durumunu yeni TTK ve kurumsal yönetim açısından değerlendirmeyi amaçlamıştır. İzmir ve Çanakkale illerindeki bağımsız denetim kuruluşlarında görev yapan sorumlu baş denetçiler ile görüşme yöntemi kullanılarak nitel bir araştırma gerçekleştirilmiştir. Yapılan çalışma sonucunda; 6102 sayılı Yeni TTK'nın bütün kurallarıyla uygulanması kurumsal yönetim ve bağımsız denetim uygulamalarının üzerinde olumlu sonuçlar doğuracağı sonucuna varılmıştır. 


\section{S.Elden Ürgüp-R.M. Bașar Bă̆ımsız Denetime İliskin Düzenlemeler...}

Özulucan vd. (2015) çalışmalarında, 6102 sayılı Yeni TTK'nın bağımsız denetim hakkında getirmiş olduğu yenilikleri açıklamayı ve bağımsız denetçi olarak görevlendirilecek meslek mensuplarının getirilen bu yenilikler hakkındaki görüşlerinin alınmasını amaçlamışlardır. Araştırma kapsamında Ordu ilinde faaliyet gösteren 197 muhasebe meslek mensuplarından 97'sine anket çalışması uygulanmıştır. Verilerin analizi yapılırken frekans analizi, One Way Anova analizi ve T-testi analizi uygulanmıştır. Araştırma sonucunda; meslek mensuplarının, denetçi olarak yetkilendirilecek olanlara sınav şartının zorunlu olması ve 15 yıllık mesleki tecrübenin aranması hakkındaki düzenlemelere katılmadıklarına fakat; bağımsız denetime ve denetçi yetkilendirmesine dair yapılan düzenlemelerin doğruluğuna ve gerekliliğine inandıkları sonucuna ulaşılmıştır.

Bulut (2015) çalışmasında, 6102 sayılı Yeni TTK ile geniş bir kapsama ulaşan bağımsız denetimin uygulama alanlarının genişletilme sebeplerini, bağımsız denetimin konusu olan finansal tablolar ve raporlar ile bağımsız denetime tabi işletmeleri ele almıştır. Bu çalışma ile bağımsız denetimde gerekli görülen birliği, uyumu, kaliteyi ve güveni sağlamak için denetim standartlarını belirlemek ve bağımsız denetimde otoriteyi elinde tutan KGK'nın yegane mecra olarak kabul edilmesi ve bu yönde yasal düzenlemelerin yapılması gerektiği sonucuna varılmıştır.

Demir vd. (2016) tarafından, bağımsız denetçi mesleği hakkında meslek mensuplarının görüşlerini kapsayan bir araştırma gerçekleştirilmiştir. Bu amaç doğrultusunda Van ilinde faaliyet gösteren bağımsız denetçilerin bağımsız denetime olan bakış açısını tespit etmek amacıyla 31 meslek mensubu ile anket gerçekleştirilmiştir. Ortaya çıkan verilerin analiz aşamasında aritmetik ortalama, standart sapma, frekans analizi ve farklılık testleri uygulanmıştır. Araştırma sonucunda; bağımsız denetim yetkisine sahip meslek mensuplarının büyük çoğunluğunun bağımsız denetimin gerekli ve faydalı olduğu görüşüne sahip olduğu ve yetkilendirme konusunda TÜRMOB yerine KGK'nın görevlendirilmiş olmasına olumsuz baktıkları saptanmıştır.

Akyüz ve Kestane (2020) yasal mevzuatlar bakımından bağımsız denetçilerin sahip olması gereken ilke ve kuralları açıklamayı amaçlamışlardır. Bu amaçla bağımsız denetçileri SPK, VUK, TTK ve BDS açısından ele alarak yasal düzenlemelerin bağımsız denetçilere karşı bakış açısı incelenmiştir. Çalışmanın sonucunda; Türkiye'de denetim faaliyetleri açısından farklı hukuki düzenlemelerin varlığı sebebiyle uygulama aşamasında birliğin sağlanabilmesi için uyumlaştırma uğraşlarının arttırılması ve denetlenen işletmelerin faaliyet alanları ve nitelikleri göz önüne alınarak denetçi bağımsızlığı kısmına getirilen düzenlemelerin yeniden gözden geçirilmesi gerektiği ortaya koyulmuştur. 


\section{ARAŞTIRMA}

\section{Araștırmanın Amacı}

Çalışmanın amacı, TR72 bölgesinde faaliyet gösteren bağımsız denetim kuruluşlarına bağlı bağımsız denetçilerin, 6102 sayılı TTK ile birlikte yapılan yasa ve yasa benzeri düzenlemelerin bağımsız denetim sürecine, bağımsız denetçilere ve işletmelere etkileri hakkındaki fikirlerinin ve farkındalıklarının ortaya çıkarılmasıdır. Bu çalışma ile birlikte yapılan yeni düzenlemelerin bağımsız denetçileri ve bağımsız denetimin kalitesini, etkinliğini ve verimliliğini nasıl etkilediğini saptamak, ortaya çıkan sorunlara ne gibi çözümler bulunacağı hakkında fikirler sunmak amaçlanmaktadır.

\section{Araştırmanın Kapsamı}

Araştırma TR72 bölgesinde yapılmıştır. Sivas, Kayseri ve Yozgat illerini kapsayan TR72 bölgesinde bağımsız denetim kuruluşlarına bağlı çalışan bağımsız denetçiler hedef kitleyi oluşturmuştur. Yozgat ilinde bağımsız denetim kuruluşu bulunmadığından Yozgat ili araştırma kapsamı dışında tutulmuştur. Bağımsız denetim kuruluşu bulunan Sivas ve Kayseri illerinde KGK'ya kayıtlı toplam 77 bağımsız denetçi bulunmaktadır. Kayıtlı bulunan 77 bağımsız denetçilerin hepsine ulaşılmış ve 43'ü Kayseri'de 20'si Sivas'ta olmak üzere toplam 63 bağımsız denetçiden geri dönüş alınarak anket çalışması gerçekleştirilmiştir.

Sivas ve Kayseri illerinde bulunan bağımsız denetim kuruluşuna bağlı bağımsız denetçilerin yasal düzenlemelerin etkileri hakkında fikirleri ve farkındalıkları tespit edilmeye çalışıldığından ilk 13 sorusu demografik son 37 sorusu ise 5'li likert tipi önermelerden oluşan toplam 50 soru ve ifadeden oluşmaktadır. Anketin 5'li likert tipi önermelerden oluşan 37 soruluk kısmı, bağımsız denetime dair yapılan yasal düzenlemelerin denetlenen işletmelere etkileri, bağımsız denetçiler ve denetim kuruluşlarına etkileri, bağımsız denetim kapsamında düzenleme yapan kurumlara etkileri ve denetim kalitesine etkileri olarak 4 bölümden oluşmaktadır.

Anket için Sivas Cumhuriyet Üniversitesi Sosyal Bilimler Etik Kurulu'ndan etik kurul onayı alınmış ve anket, gönüllü olarak çalışmaya katılan ve çalışma grubunda yer alan bağımsız denetçilere yüz yüze olarak uygulanmıştır.

\section{Araştırmanın Yöntemi}

Araştırmada veri toplama yöntemlerinden biri olan anket yöntemi kullanılmıştır. Anket verileri toplanırken online anket yöntemi tercih edilmiştir. Online formatta düzenlenen anketler e-mail yoluyla denetçilere ulaştırılmıştır. 
S.Elden Ürgüp-R.M. Başar $\quad$ Bağımsız Denetime İlisskin Düzenlemeler...

KGK'ya kayıtl1, Sivas ve Kayseri illerinde faaliyet gösteren ve bağımsız denetim kuruluşlarına bağlı 77 bağımsız denetçi ile e-mail üzerinden iletişime geçilmiş ve 63'ünden geri dönüş alınmıştır. Anket soruları; Ertaş (2018) çalışmasından alınarak online formata aktarılmıştır.

\section{Araştırmanın Analizi ve Genel Güvenilirlik Değerleri}

Anket verilerinin analizinde SPSS 26 istatistiki paket programı kullanılmıştır. $\mathrm{Bu}$ program ile veriler üzerinden frekans, yüzde, ortalama ve standart sapma hesaplanmış ayrıca Ki-Kare Bağımsızlık Testi yapılmıştır.

Güvenilirlik analizinde Cronbach Alfa katsayısı kullanılmaktadır. 0 ile 1 arasında değer alan Alfa $(\alpha)$ katsayısı aşağıdaki gibi yorumlanmaktadır (Kalaycı, 2010:405);

- $\quad 0,00<\alpha<0,40$ ise ölçek güvenilir değildir,

- $\quad 0,40<\alpha<0,60$ ise ölçeğin güvenilirliği düşüktür,

- $0,60<\alpha<0,80$ ise ölçek oldukça güvenilirdir,

- $\quad 0,80<\alpha<1,00$ ise ölçek yüksek derecede güvenilirdir şeklinde ifade

edilebilir.

Yapılan güvenilirlik analizinde Cronbach's Alfa katsayısı 0,964 olarak hesaplanmıştır. $\mathrm{Bu}$ değer anketin güvenilirliğinin oldukça yüksek olduğunu göstermektedir.

\section{Araştırma Bulgularının Değerlendirilmesi}

Yapılan araştırma sonucunda elde edilen veriler dört bölüm şeklinde analiz edilmekte ve yorumlanmaktadır. Birinci bölümde demografik bilgiler, ikinci bölümde denetim sırasında karşılaşılan sorunlar, üçüncü bölümde ölçeklere ilişkin bilgiler ve dördüncü bölümde de denetim kalitesini artırmaya yönelik önermelerin analizi ve yorumu yapılmaktadır.

\section{Araştırmaya Katılan Bağımsız Denetçilerin Demografik Özelliklerine Dair Bilgiler}

Katılımcılardan elde edilen demografik verilere ilişkin frekans analizi sonuçları Tablo 1'deki gibidir.

Tablo 1. Demografik Özelliklere İlişkin Frekans Analizi Sonuçları

\begin{tabular}{|c|c|c|c|c|c|}
\hline & $\begin{array}{l}\text { Frekan } \\
\text { S (f) }\end{array}$ & $\begin{array}{l}\text { Yüzd } \\
\text { e (\%) }\end{array}$ & & $\begin{array}{l}\text { Frekan } \\
\text { S (f) }\end{array}$ & $\begin{array}{l}\text { Yüzd } \\
\text { e (\%) }\end{array}$ \\
\hline Kadın & 4 & 6,3 & Evli & 58 & 92,1 \\
\hline
\end{tabular}




\begin{tabular}{|c|c|c|c|c|c|c|c|}
\hline Cinsiyet & Erkek & 59 & 93,7 & $\begin{array}{l}\text { Medeni } \\
\text { Durum }\end{array}$ & Bekar & 5 & 7,9 \\
\hline \multirow{4}{*}{$\begin{array}{l}\text { Yaş } \\
\text { Gruplar } \\
\text { I }\end{array}$} & $\begin{array}{l}22-29 \\
\text { Yaş }\end{array}$ & 4 & 6,3 & \multirow{4}{*}{$\begin{array}{l}\text { SMMM/YM } \\
\text { M } \\
\text { de Çalışma } \\
\text { Süresi }\end{array}$} & $1-5 Y_{1}$ & 5 & 7,9 \\
\hline & $\begin{array}{l}30-37 \\
\text { Yaş } \\
\end{array}$ & 5 & 7,9 & & $\begin{array}{l}\text { 6-10 } \\
\text { Y11 } \\
\end{array}$ & 8 & 12,7 \\
\hline & $\begin{array}{l}38-45 \\
\text { Yaș }\end{array}$ & 25 & 39,7 & & $\begin{array}{l}11-15 \\
\text { Y11 }\end{array}$ & 40 & 63,5 \\
\hline & $\begin{array}{l}46 \mathrm{ve} \\
\text { Üzeri }\end{array}$ & 29 & 46,0 & & $15+$ & 10 & 15,9 \\
\hline \multirow[t]{2}{*}{$\begin{array}{l}\text { Eğitim } \\
\text { Düzeyi }\end{array}$} & $\begin{array}{l}\text { Lisan } \\
\mathrm{s}\end{array}$ & 52 & 82,5 & \multirow{2}{*}{$\begin{array}{l}\text { Mesleki } \\
\text { Unvan }\end{array}$} & $\begin{array}{l}\text { SMM } \\
\text { M }\end{array}$ & 52 & 82,5 \\
\hline & $\begin{array}{l}\text { Lisan } \\
\text { s } \\
\text { Üstü }\end{array}$ & 11 & 17,5 & & YMM & 11 & 17,5 \\
\hline
\end{tabular}

Tablo 1'e göre Sivas ve Kayseri illerinde faaliyette bulunarak ankete katılan meslek mensuplarının \%93,7'si erkek, \%6,3'ü ise kadındır. Verilere göre mesleği icra eden kadınların oranının erkeklerin oranından çok daha düşük olduğu görülmektedir. Buradan bağımsız denetçi mesleğini erkeklerin kadınlardan daha fazla tercih ettiği anlaşılmaktadır. Çalışma sürelerine bakıldığında 11-15 yıl arası hizmette bulunan meslek mensuplarının \%63,5 oranla daha fazla olduğu gözlemlenmiştir. Bağımsız denetçilerin çoğunlukla orta yaş ve üstü ve 11-15 yıl aras1 faaliyette bulunduğu anlaşılmaktadır. Eğitim düzeyi açısından ise \%82,5 gibi yüksek bir oranla lisans düzeyi daha fazladır ve \%17,5 oranında ise lisansüstü düzey bulunmaktadır. Ankete katılanlardan serbest muhasebeci mali müşavirler $\% 82,5$ oranında ve yeminli mali müşavirler $\% 17,5$ oranındadır. Buradan bağımsız denetçi görevini yürüten meslek mensuplarının çoğunluğunun serbest muhasebeci mali müşavirler olduğu görülmektedir.

\section{Denetim Faaliyetlerini Yaparken Karşılaşılan Sorunlar}

Katılımcılara anket formunda, denetim faaliyeti yürütülürken karşılaştıkları 9 sorun yöneltilmiş ve karşılaşılan en önemli 3 sorunu işaretlemeleri istenmiştir. Karşılaştıkları sorunlar Tablo 2'de verilmiştir.

Tablo 2. Bağımsız Denetçilerin Denetim Faaliyetlerinde Karşılaştığı Sorunlar

\begin{tabular}{l|c|c}
\hline \multicolumn{1}{c|}{ Öngörülen Sorunlar } & Toplam & \% \\
\hline Halen vergi muhasebesi standartlarının uygulanması & 15 & 11,36 \\
\hline Denetlenen işletmelerin UMS'nı uygulamaması & 13 & 9,84 \\
\hline Denetime ilişkin düzenlemelerin yetersizliği & 16 & 12,12 \\
\hline GKGD standartlarına uyumun sağlanamamış olması & 7 & 5,30 \\
\hline Denetim firmaları arasında yaşanan rekabet & 17 & 12,87 \\
\hline
\end{tabular}


S.Elden Ürgüp-R.M. Başar $\quad$ Bağımsız Denetime İlisskin Düzenlemeler...

\begin{tabular}{l|c|c}
\hline Otorite fazlalığı ve bunun yarattığı sorunlar & 10 & 7,57 \\
\hline Mesleki eğitim ve yeterliliğe gereken önemin verilmemesi & 16 & 12,12 \\
\hline Mevzuat karmaşası & 16 & 12,12 \\
\hline $\begin{array}{l}\text { Yapılan denetim işleminin kapsamının işletme yönetimi } \\
\text { tarafından bilinmemesi }\end{array}$ & 22 & $\mathbf{1 6 , 6 6}$ \\
\hline Toplam & $\mathbf{1 3 2}$ & $\mathbf{1 0 0 . 0 0}$ \\
\hline
\end{tabular}

Tablo 2'deki bulgulara göre bağımsız denetçilerin denetim sürecinde karşılaştıkları en önemli 3 sorunu sıralarken; birinci sırada \%16,66 oranla "Yapılan denetim işleminin kapsamının işletme yönetimi tarafindan bilinmemesi" sorunu yer almaktadır. İkinci sıray $\% 12,87$ oran ile "Denetim firmaları arasında yaşanan rekabet" sorunu yer alırken üçüncü sırayı 3 sorun birlikte paylaşmaktadır. Bunlar; "Denetime ilişkin düzenlemelerin yetersizliği, Mesleki eğitim ve yeterliliğe gereken önemin verilmemesi, Mevzuat karmaşası". Karşılaşılan sorunların sıralaması Tablo 3'te gösterilmiştir.

Tablo 3. Denetim Faaliyetleri Yapılırken Karşılaşılan En Önemli 3 Sorun

\begin{tabular}{l}
\hline 1. Yapılan denetim işleminin kapsamının işletme yönetimi tarafından bilinmemesi \\
\hline 2. Denetim firmaları arasında yaşanan rekabet \\
\hline 3. Denetime ilişkin düzenlemelerin yetersizliği, Mesleki eğitim ve yeterliliğe gereken \\
önemin verilmemesi, Mevzuat karmaşası.
\end{tabular}

Denetim faaliyetlerinin yürütüldüğü sırada bağımsız denetimin kapsamı ve firmalar arası yaşanan rekabetler en önemli sorunlar olarak ortaya çıkmıştır. Karmaşık ve fazla mevzuatın bulunması ve mesleki açıdan verilen eğitimlerin yetersizliği diğer önemli sorunlardır.

\section{Ölçeklere İlişkin Yüzde, Ortalama Ve Standart Sapma Değerleri}

Anketin son 37 sorusunu oluşturan ölçeğe göre hazırlanmış bölüm 4 alt başlıkta incelenmiştir.

\section{Denetlenen İşletmelere Etkiler}

Denetlenen işletmelere etkilerinin analizi için oluşturulan sorular ve verilerin yüzdeleri, ortalamaları ve standart sapma değerleri Tablo 4'te gösterilmiştir. 
Tablo 4. Denetlenen İşletmelere Etkiler

\begin{tabular}{|c|c|c|c|c|}
\hline & & $\%$ & Ortalama & $\begin{array}{c}\text { Standart } \\
\text { Sapma }\end{array}$ \\
\hline $\begin{array}{l}2020 \text { yılı için zorunlu denetime dahil olacak } \\
\text { şirketlerin ( } 35 \text { milyon TL aktif toplam, } 70 \text { milyon } \\
\text { TL net satış hasılatı ve } 175 \text { çalışan)kapsamı daha da } \\
\text { genişletilmelidir. }\end{array}$ & $\begin{array}{l}1 \\
2 \\
3 \\
4 \\
5\end{array}$ & $\begin{array}{c}14,3 \\
15,9 \\
9,5 \\
34,9 \\
25,4\end{array}$ & 3,41 & 1,398 \\
\hline $\begin{array}{l}\text { Bağımsız denetimin tüm sermaye şirketlerine } \\
\text { uygulanmasına ilişkin, kademeli geçiş } \\
\text { takvimlendirilerek ilan edilmelidir. }\end{array}$ & $\begin{array}{l}1 \\
2 \\
3 \\
4 \\
5\end{array}$ & $\begin{array}{c}12,7 \\
11,1 \\
9,5 \\
42,9 \\
23,8\end{array}$ & 3,53 & 1,317 \\
\hline $\begin{array}{l}\text { Denetlenen İşletmeler, bağımsız denetime tabi } \\
\text { tutulması ile elde edecekleri fayda, katlanacakları } \\
\text { maliyetlerinden fazla olduğunu düşünürler. }\end{array}$ & $\begin{array}{l}1 \\
2 \\
3 \\
4 \\
5 \\
\end{array}$ & $\begin{array}{l}11,1 \\
19,0 \\
12,7 \\
39,7 \\
17,5\end{array}$ & 3,33 & 1,282 \\
\hline $\begin{array}{l}\text { Denetlenen şirketlerin muhasebe elemanları, TFRS, } \\
\text { TMS ve Denetim standartları ile ilgili yeterli bilgileri } \\
\text { mevcut değildir. }\end{array}$ & $\begin{array}{l}1 \\
2 \\
3 \\
4 \\
5 \\
\end{array}$ & $\begin{array}{c}9,5 \\
12,7 \\
7,9 \\
34,9 \\
34,9 \\
\end{array}$ & 3,73 & 1,322 \\
\hline $\begin{array}{l}\text { Türkiye'de denetlenen şirketler bağımsız denetime } \\
\text { gereken önemi vermemektedir. }\end{array}$ & $\begin{array}{l}1 \\
2 \\
3 \\
4 \\
5\end{array}$ & $\begin{array}{c}9,5 \\
9,5 \\
7,9 \\
49,2 \\
23,8\end{array}$ & 3,68 & 1,215 \\
\hline
\end{tabular}

Bağımsız denetime tabi firmaların bağımsız denetime ilişkin bilgi seviyeleri ile bağımsız denetime verdikleri önem arasındaki ilişki düzeyi çapraz tablo ile Tablo 5'te gösterilmiştir.

Tablo 5. Bağımsız Denetime Tabi Firmaların Bilgi Seviyeleri ve Bağımsız Denetime Verdikleri Önem Arasındaki İlişki Düzeyi

(E) Türkiye'de denetlenen işletmeler bağımsız denetime gereken önemi vermemektedir.

\begin{tabular}{c|c|c|c|c|c|c|c}
\hline & & 1 & 2 & 3 & 4 & 5 & Toplam \\
\cline { 3 - 8 } & & $\%$ & $\%$ & $\%$ & $\%$ & $\%$ & $\%$ \\
\hline
\end{tabular}


S.Elden Ürgüp-R.M. Başar $\quad$ Bağımsız Denetime İlisskin Düzenlemeler...

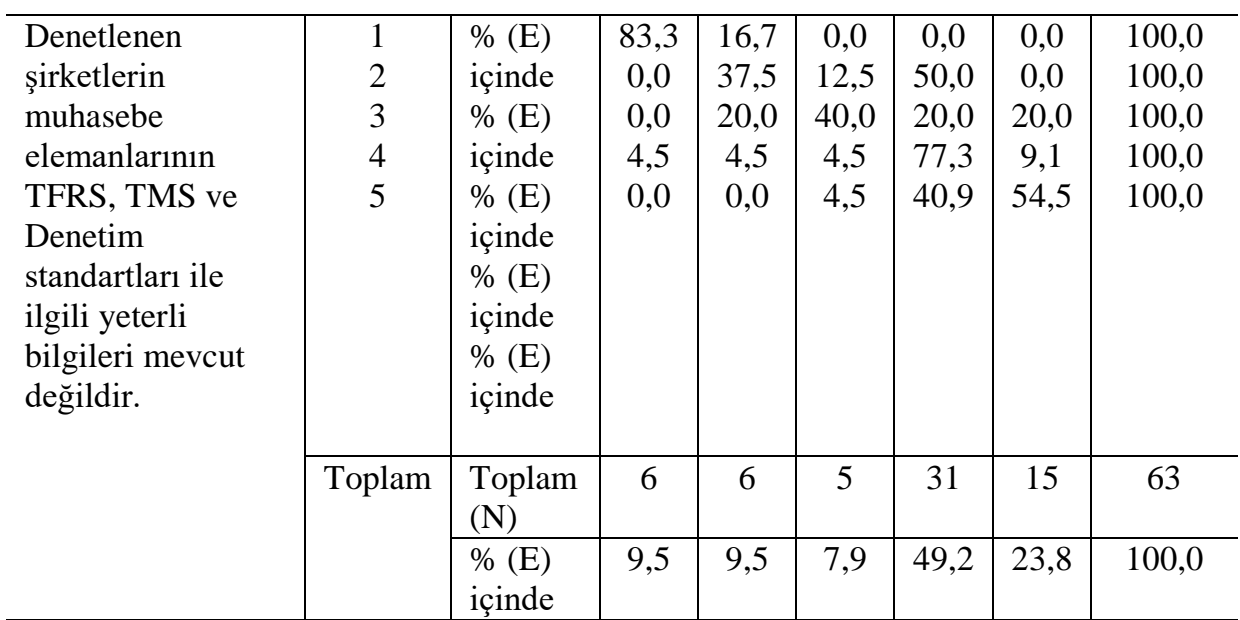

Tablo 6. Ki-Kare Test Tablosu

\begin{tabular}{l|c|c|c}
\hline & Value & df & Asymp. Sig. (2-sided) \\
\hline Ki-Kare & $77,912^{\mathrm{a}}$ & 16 &, 000 \\
\hline Likelihood Ratio & 60,750 & 16 &, 000 \\
\hline Linear-by-Linear Association & 33,804 & 1 &, 000 \\
\hline Geçerli Anket & 63 & & \\
\hline
\end{tabular}

Tablo 6'da Bağımsız denetime dair yeterli bilgiye sahip olmayan ve gerekli önemi vermeyen denetlenen işletmelerin aynı zamanda bağımsız denetim maliyetlerini de yüksek bulduğu görülmüştür. Anlamlılık değeri $p=0,000$ olarak görülmektedir. $\mathrm{Bu}$ değer $\mathrm{p}<0,05$ şartını sağladığı için bağımsız denetime tabi firmaların bağımsız denetime dair bilgi seviyeleri ile denetime verdikleri önem arasındaki ilişki anlamlıdır. Böylece bağımsız denetime tabi işletmelerin bilgi seviyelerinin yetersiz olması sonucunda bağımsız denetime yeterli önemi de vermedikleri söylenebilir.

\section{Bağımsız Denetçiler Ve Denetim Kuruluşlarına Etkiler}

Bağımsız denetim kapsamında yapılan yasal düzenlemelerin bağımsız denetçiler ve denetim kuruluşlarına etkilerinin analizinde yöneltilen sorular ve verilerin yüzdeleri, ortalamaları ve standart sapma değerleri Tablo 7'de verilmiştir. 
Tablo 7. Bağımsız Denetçiler ve Denetim Kuruluşlarına Etkiler

\begin{tabular}{|c|c|c|c|c|}
\hline & & $\%$ & Ortalama & $\begin{array}{l}\text { Standart } \\
\text { Sapma }\end{array}$ \\
\hline $\begin{array}{l}\text { Denetimin, denetim firması aracılığı ile } \\
\text { yapılması denetim kalitesini arttırır. }\end{array}$ & $\begin{array}{l}1 \\
2 \\
3 \\
4 \\
5\end{array}$ & $\begin{array}{c}7,9 \\
11,1 \\
11,1 \\
23,8 \\
46,0\end{array}$ & 3,88 & 1,321 \\
\hline $\begin{array}{l}\text { SPK mevzuatına göre SPK da kayıtlı firmaların } \\
\text { denetiminin, denetim firmaları tarafından } \\
\text { yapılması olumlu bir düzenlemedir. }\end{array}$ & $\begin{array}{l}1 \\
2 \\
3 \\
4 \\
5\end{array}$ & $\begin{array}{c}11,1 \\
7,9 \\
11,1 \\
41,3 \\
28,6\end{array}$ & 3,68 & 1,280 \\
\hline $\begin{array}{l}\text { Bağımsız denetçilik mesleki sorumluluk sigorta } \\
\text { primleri, oluşturulacak ortak bir fonda } \\
\text { toplanması, bağımsız denetimde otokontrol } \\
\text { sistemini oluşturacaktır. }\end{array}$ & $\begin{array}{l}1 \\
2 \\
3 \\
4 \\
5\end{array}$ & $\begin{array}{c}7,9 \\
14,3 \\
19,0 \\
49,2 \\
9,5\end{array}$ & 3,38 & 1,098 \\
\hline $\begin{array}{l}\text { Yasal boşluklar nedeniyle denetçi veya denetim } \\
\text { firmaları, müşteri portföylerini koruyabilmek } \\
\text { için denetimi olumsuz etkileyecek ödünler } \\
\text { vermektedir. }\end{array}$ & $\begin{array}{l}1 \\
2 \\
3 \\
4 \\
5\end{array}$ & $\begin{array}{c}4,8 \\
23,8 \\
15,9 \\
36,5 \\
19,0\end{array}$ & 3,41 & 1,186 \\
\hline $\begin{array}{l}\text { Denetimde, denetim kuruluşlarının } \\
\text { tekelleşmesinin önüne geçecek bir yapı } \\
\text { oluşturulmalıdır. }\end{array}$ & $\begin{array}{l}1 \\
2 \\
3 \\
4 \\
5\end{array}$ & $\begin{array}{c}14,3 \\
1,6 \\
1,6 \\
38,1 \\
44,4\end{array}$ & 3,96 & 1,355 \\
\hline $\begin{array}{l}\text { Denetim kuruluşlarına denetim yetkisinin, } \\
\text { sektörler bazında verilmesi denetimde etkinliği } \\
\text { artırır. }\end{array}$ & $\begin{array}{l}1 \\
2 \\
3 \\
4 \\
5\end{array}$ & $\begin{array}{l}11,1 \\
25,4 \\
27,0 \\
25,4 \\
11,1\end{array}$ & 3,00 & 1,191 \\
\hline $\begin{array}{l}\text { Türkiye'de kurulan denetim firmalarının, yurt } \\
\text { dışında faaliyet gösterebilmeleri için teknik } \\
\text { destek ve teşvikler yeterlidir. }\end{array}$ & $\begin{array}{l}1 \\
2 \\
3 \\
4 \\
5\end{array}$ & $\begin{array}{c}22,2 \\
42,9 \\
15,9 \\
9,5 \\
9,5\end{array}$ & 2,41 & 1,213 \\
\hline $\begin{array}{l}\text { Denetçilerin yetiştirilmesinde, Yasal boşluklar } \\
\text { nedeniyle, Mesleki eğitim ve yeterliliğe } \\
\text { gereken önem verilmemektedir. }\end{array}$ & $\begin{array}{l}1 \\
2 \\
3 \\
4 \\
5\end{array}$ & $\begin{array}{c}9,5 \\
20,6 \\
11,1 \\
41,3 \\
17,5\end{array}$ & 3,36 & 1,261 \\
\hline $\begin{array}{l}\text { Farklı üniversiteler / Kurumlar tarafindan } \\
\text { verilen eğitimler standart değildir. }\end{array}$ & $\begin{array}{l}1 \\
2\end{array}$ & $\begin{array}{c}4,8 \\
20,6 \\
\end{array}$ & & \\
\hline
\end{tabular}


S.Elden Ürgüp-R.M. Bașar $\quad$ Bağımsız Denetime İlisskin Düzenlemeler...

\begin{tabular}{l|c|c|c|c}
\hline & 3 & 14,3 & 3,53 & 1,202 \\
& 4 & 36,5 & & \\
\hline Denetimde kalitenin arttırılması amacıyla, & 5 & 23,8 & & \\
Üniversitelerde "MALİ DENETìM " & 2 & 4,8 & & \\
bölümünün oluşturulması meslek elemanlarının & 3 & 11,1 & & \\
yetiştirilmesine katkı sağlayacaktır. & 4 & 39,7 & 3,82 & 1,143 \\
& 5 & 31,7 & & \\
\hline Verilen denetim sertifikaların yurtdışındaki & 1 & 6,3 & & \\
sertifikasyonlarla uyumlu hale getirilmesi, & 2 & 9,5 & & \multirow{2}{*}{1,180} \\
bağımsız denetim mesleğini etkin ve itibarlı & 3 & 11,1 & 3,84 & \\
hale getirecektir. & 4 & 39,7 & & \\
& 5 & 33,3 & & \\
\hline
\end{tabular}

"Denetim kuruluşlarının tekelleşmesinin önüne geçecek bir yapı olușturulmalıdır" ve "denetim kurulușlarına denetim yetkisinin sektörler bazında verilmesi denetimde etkinliği artırır" ifadelerinin arasındaki ilişki düzeyinin tespiti çapraz tablo ile Tablo 8'de gösterilmiştir.

Tablo 8. Denetim Yetkisinin Sektörler Bazında Verilmesi ve Denetimdeki Etkinlik Düzeyi

(E) Denetim kuruluşlarına denetim yetkisinin, sektörler bazında verilmesi denetimde etkinliği artirır.

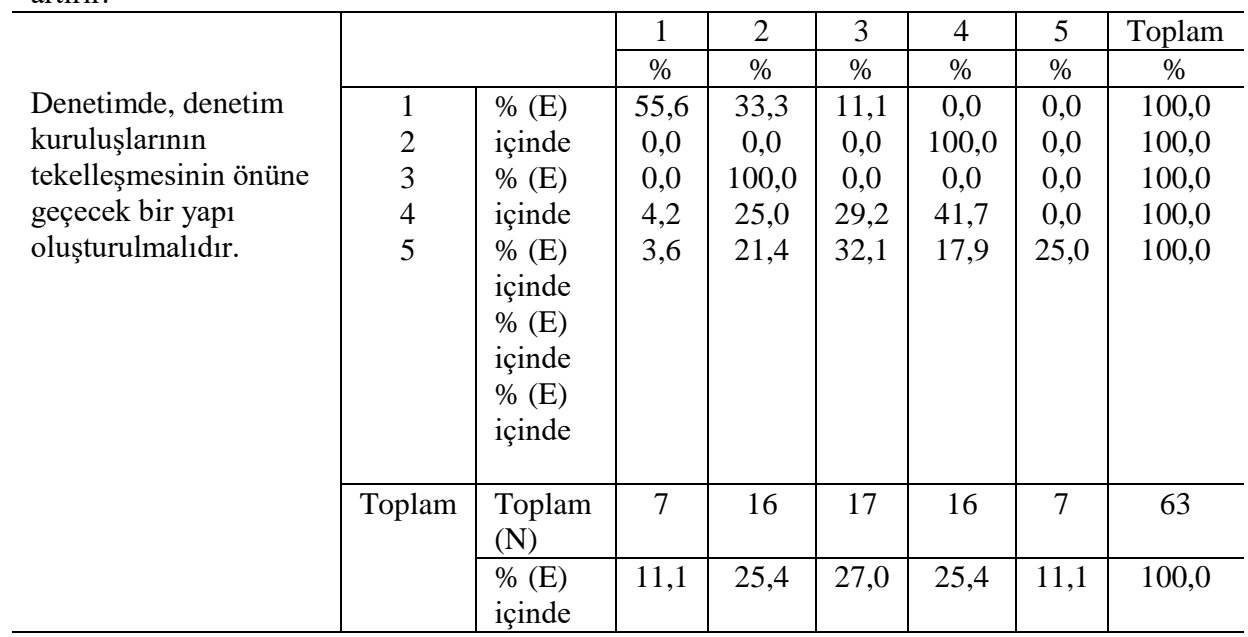


Tablo 9. Ki-Kare Test Tablosu

\begin{tabular}{l|c|c|c}
\hline & Value & df & Asymp. Sig. (2-sided) \\
\hline Ki-Kare & $39,848^{\mathrm{a}}$ & 16 &, 001 \\
\hline Likelihood Ratio & 36,944 & 16 &, 002 \\
\hline Linear-by-Linear Association & 14,847 & 1 &, 000 \\
\hline Geçerli Anket & 63 & & \\
\hline
\end{tabular}

Tablo 9'da araştırmalar kapsamında denetim şirketlerinde tekelleşmenin varolduğu görülmektedir. Tabloda anlamlılık değeri $\mathrm{p}<0,05$ olarak görülmekte ve bu da tekelleşmenin önüne geçecek bir yapının oluşturulması düşüncesinin ağır bastı̆̆ını göstermektedir. Ayrıca anlamlı bir farklılık olduğundan denetim yetkisinin sektör bazlı verilmesinin denetimde etkinliği artıracağı ve dolayısıyla denetim kalitesini olumlu yönde etkileyeceği ve bu kalite ile tekelleşmenin önüne geçilebileceği söylenebilir.

\section{Bağımsız, Denetim Kapsamında Düzenleme Yapan Kurumlara Etkiler}

Yapılan yasal düzenlemelerin bağımsız denetim kapsamında düzenleme yapan kurumlara etkilerini analiz etmek amaciyla sorulan sorular ve verilerin yüzdeleri, ortalamaları ve standart sapma değerleri Tablo 10'da gösterilmiştir.

Tablo 10. Bağımsız Denetim Kapsamında Düzenleme Yapan Kurumlara Etkiler

\begin{tabular}{l|c|c|c|c}
\hline & & $\%$ & Ortalama & $\begin{array}{c}\text { Standart } \\
\text { Sapma }\end{array}$ \\
\hline KGK, gözetim işlemlerini yerine getirecek bir & 1 & 7,9 & & \\
üst gözetim kurumu olmalıdır. & 2 & 17,5 & & 1,255 \\
& 3 & 11,1 & 3,53 & \\
& 4 & 39,7 & & \\
\hline KGK üyelerinin, seçim veya atamaları & 5 & 23,8 & & \\
yapılırken Akademisyen, SMMM, YMM gibi & 2 & 4,8 & & \\
mesleki unvan şartı aranmalıdır. & 3 & 3,2 & 3,84 & \\
& 4 & 44,4 & & \\
& 5 & 34,9 & & \\
\hline Denetim standartlarını belirleme yetkisi, & 1 & 6,3 & & \\
denetim uygulamacılarının ve akademik & 2 & 12,7 & & \\
temsilcilerin yer aldığı bir özerk kuruma & 3 & 11,1 & 3,74 & \\
bırakılmalıdır. & 4 & 39,7 & & \\
& 5 & 30,2 & & \\
\hline
\end{tabular}


S.Elden Ürgüp-R.M. Başar $\quad$ Bağımsız Denetime İlisskin Düzenlemeler...

\begin{tabular}{|c|c|c|c|c|}
\hline $\begin{array}{l}\text { Bağımsız denetçileri tek çatı altında toplayacak } \\
\text { mesleki bir örgüt oluşturulmalıdır. }\end{array}$ & $\begin{array}{l}1 \\
2 \\
3 \\
4 \\
5\end{array}$ & $\begin{array}{c}6,3 \\
14,3 \\
9,5 \\
33,3 \\
36,5\end{array}$ & 3,79 & 1,259 \\
\hline $\begin{array}{l}\text { Denetim firmaları tarafindan hazırlanan } \\
\text { denetim raporlarının Kamuyu aydınlatmada ve } \\
\text { şeffaflıkta başarı sağlanmıştır. }\end{array}$ & $\begin{array}{l}1 \\
2 \\
3 \\
4 \\
5\end{array}$ & $\begin{array}{c}12,7 \\
15,9 \\
31,7 \\
30,2 \\
9,5\end{array}$ & 3,07 & 1,168 \\
\hline $\begin{array}{l}\text { SPK ve BDDK kanunlarında yapılan son } \\
\text { değişikliklerle denetimde çok başlı yapı } \\
\text { olmuş̧ur. }\end{array}$ & $\begin{array}{l}1 \\
2 \\
3 \\
4 \\
5\end{array}$ & $\begin{array}{r}0,0 \\
17,5 \\
28,6 \\
38,1 \\
15,9\end{array}$ & 3,52 & 0,964 \\
\hline $\begin{array}{l}\text { Kamu Gözetimi Kurumu; bağımsız denetim } \\
\text { kuruluşlarını yetkilendirmek ve bunların } \\
\text { faaliyetlerini denetlemekte başarılı olmuştur. }\end{array}$ & $\begin{array}{l}1 \\
2 \\
3 \\
4 \\
5\end{array}$ & $\begin{array}{c}9,5 \\
17,5 \\
27,0 \\
39,7 \\
6,3\end{array}$ & 3,15 & 1,095 \\
\hline $\begin{array}{l}\text { KGK, SPK, BDDK, EPDK, Hazine gibi } \\
\text { kurumların koordinasyonun sağlanmalı ve talep } \\
\text { edilen farklı rapor formatlarının yeknesak hale } \\
\text { getirilmelidir. }\end{array}$ & $\begin{array}{l}1 \\
2 \\
3 \\
4 \\
5\end{array}$ & $\begin{array}{c}6,3 \\
12,7 \\
7,9 \\
42,9 \\
30,2\end{array}$ & 3,77 & 1,197 \\
\hline
\end{tabular}

6102 sayılı TTK ile getirilen yasal düzenlemeler ile hazırlanan denetim raporlarına olan güvenin sağlanma düzeyi çapraz tablo ile Tablo 11'de gösterilmiştir.

Tablo 11. Yasal Düzenlemeler ile Hazırlanan Denetim Raporlarına Olan Güven Sağlanma Düzeyi

(C) Yapılan yasal düzenlemeler ile hazırlanan denetim raporlarına olan güven sağlanmıştır. 


\begin{tabular}{|c|c|c|c|c|c|c|c|c|}
\hline \multirow[t]{3}{*}{$\begin{array}{l}6012 \text { Sayılı Türk } \\
\text { Ticaret Kanunun } \\
\text { ve } 6335 \text { Sayılı } \\
\text { Kanunla } \\
\text { getirilen } \\
\text { düzenlemeler, } \\
\text { Genel kabul } \\
\text { görmüş denetim } \\
\text { standartlarıyla } \\
\text { uyumludur. }\end{array}$} & $\begin{array}{l}1 \\
2 \\
3 \\
4 \\
5\end{array}$ & $\begin{array}{l}\%(\mathrm{C}) \\
\text { içinde } \\
\%(\mathrm{C}) \\
\text { içinde } \\
\%(\mathrm{C}) \\
\text { içinde } \\
\%(\mathrm{C}) \\
\text { içinde } \\
\%(\mathrm{C}) \\
\text { içinde }\end{array}$ & $\begin{array}{c}33,3 \\
26,7 \\
5,6 \\
0,0 \\
40,0\end{array}$ & $\begin{array}{c}33,3 \\
26,7 \\
16,7 \\
4,5 \\
0,0\end{array}$ & $\begin{array}{c}0,0 \\
20,0 \\
27,8 \\
22,7 \\
0,0\end{array}$ & $\begin{array}{l}33,3 \\
26,7 \\
44,4 \\
68,2 \\
20,0\end{array}$ & $\begin{array}{c}0,0 \\
0,0 \\
5,6 \\
4,5 \\
40,0\end{array}$ & $\begin{array}{l}100,0 \\
100,0 \\
100,0 \\
100,0 \\
100,0\end{array}$ \\
\hline & Toplam & $\begin{array}{l}\text { Toplam } \\
\text { (N) }\end{array}$ & 8 & 9 & 13 & 29 & 4 & 63 \\
\hline & & $\begin{array}{l}\%(\mathrm{C}) \\
\text { içinde }\end{array}$ & 12,7 & 14,3 & 20,6 & 46,0 & 6,3 & 100,0 \\
\hline
\end{tabular}

Tablo 12. Ki-Kare Test Tablosu

\begin{tabular}{l|c|c|c}
\hline & Value & df & Asymp. Sig. (2-sided) \\
\hline Ki-Kare & $31,135^{\mathrm{a}}$ & 16 &, 013 \\
\hline Likelihood Ratio & 30,846 & 16 &, 014 \\
\hline Linear-by-Linear Association & 8,597 & 1 &, 003 \\
\hline Geçerli Anket & 63 & & \\
\hline
\end{tabular}

Tablo 12'de anlamlılık değerinin $\mathrm{p}<0,05$ olduğu görülmektedir. Bu durumda yasal düzenlemelerin yapılması ile birlikte bağımsız denetim kuruluşları tarafından hazırlanan denetim raporları arasında anlamlı bir ilişki vardır. Yani denetçilerin yasal düzenlemeler çerçevesinde KGK'nın denetim faaliyetlerini yürütmesi gerektiğinin düşünüldüğü, hazırlanan denetim raporlarının güvenilir ve şeffaf olduğu düşüncesinin varolduğu söylenebilir. KGK'nın bağımsız denetim kuruluşlarını yetkilendirmede ve bu kuruluşların faaliyetlerini denetlemede başarı elde ettiği böylece yapılan yasal düzenlemeler ile birlikte denetim raporlarına olan güveni artırdığı söylenebilir.

\section{Denetim Kalitesine Etkiler}

Yapılan yasal düzenlemelerin denetim kalitesine etkilerini saptamak için yapılan analizde yöneltilen sorular ve verilerin yüzdeleri, ortalamaları ve standart sapma değerleri Tablo 13'de gösterilmiş̧ir. 
S.Elden Ürgüp-R.M. Bașar Bağımsız Denetime İlisskin Düzenlemeler...

Tablo 13: Denetim Kalitesine Etkiler

\begin{tabular}{|c|c|c|c|c|}
\hline & & $\%$ & Ortalama & $\begin{array}{c}\text { Standart } \\
\text { Sapma }\end{array}$ \\
\hline $\begin{array}{l}\text { 6012 Sayılı Türk Ticaret Kanunun ve } 6335 \\
\text { Sayılı Kanunla getirilen düzenlemeler, Genel } \\
\text { kabul görmüş denetim standartlarıyla } \\
\text { uyumludur. }\end{array}$ & $\begin{array}{l}1 \\
2 \\
3 \\
4 \\
5\end{array}$ & $\begin{array}{c}4,8 \\
23,8 \\
28,6 \\
34,9 \\
7,6\end{array}$ & 3,17 & 1,040 \\
\hline $\begin{array}{l}\text { Yeni TTK ya göre denetçi yedi y1l arka arkaya } \\
\text { aynı şirket için denetleme raporu vermişse, o } \\
\text { denetçi en az iki yıl değiştirilme mecburiyeti } \\
\text { olumlu bir düzenlemedir. }\end{array}$ & $\begin{array}{l}1 \\
2 \\
3 \\
4 \\
5\end{array}$ & $\begin{array}{l}14,3 \\
12,7 \\
6,3 \\
49,2 \\
17,5\end{array}$ & 3,42 & 1,316 \\
\hline $\begin{array}{l}\text { Yapılan yasal düzenlemeler ile hazırlanan } \\
\text { denetim raporlarına olan güven sağlanmıştır. }\end{array}$ & $\begin{array}{l}1 \\
2 \\
3 \\
4 \\
5\end{array}$ & $\begin{array}{c}12,7 \\
14,3 \\
20,6 \\
46,0 \\
6,3\end{array}$ & 3,19 & 1,161 \\
\hline $\begin{array}{l}\text { İş sahiplerine, bağımsız denetime tabi } \\
\text { olmasının sağlayacağı faydalar anlatılması } \\
\text { denetim kalitesini arttıracaktır. }\end{array}$ & $\begin{array}{l}1 \\
2 \\
3 \\
4 \\
5\end{array}$ & $\begin{array}{c}11,1 \\
12,7 \\
3,2 \\
46,0 \\
27,0\end{array}$ & 3,65 & 1,309 \\
\hline $\begin{array}{l}\text { Denetim kapsamına giren işletmelerin yetkili } \\
\text { personeline, TFRS ve denetim konularında kısa } \\
\text { süreli eğitim mecburiyeti getirilmesi denetim } \\
\text { kalitesini arttıracaktır. }\end{array}$ & $\begin{array}{l}1 \\
2 \\
3 \\
4 \\
5\end{array}$ & $\begin{array}{c}9,5 \\
9,5 \\
12,7 \\
33,3 \\
34,9\end{array}$ & 3,74 & 1,294 \\
\hline $\begin{array}{l}\text { Yapılan yasal düzenlemelerle muhasebe } \\
\text { standartları ve bağımsız denetim standartlarının } \\
\text { benimsenmesi ve uygulanmasında kamu bilinci } \\
\text { oluşmamıştır. }\end{array}$ & $\begin{array}{l}1 \\
2 \\
3 \\
4 \\
5\end{array}$ & $\begin{array}{l}11,1 \\
14,3 \\
12,7 \\
36,5 \\
25,4\end{array}$ & 3,50 & 1,318 \\
\hline $\begin{array}{l}\text { TMS, TFRS ve Vergi Usul Kanunu arasında, } \\
\text { muhasebeleştirme ve raporlamadaki farklılıklar } \\
\text { denetimi olumsuz etkilemektedir. }\end{array}$ & $\begin{array}{l}1 \\
2 \\
3 \\
4 \\
5\end{array}$ & $\begin{array}{c}3,2 \\
17,5 \\
4,8 \\
52,4 \\
22,2\end{array}$ & 3,73 & 1,095 \\
\hline
\end{tabular}




\begin{tabular}{|c|c|c|c|c|}
\hline $\begin{array}{l}\text { TMS, TFRS ve Vergi mevzuatı ivedilikle } \\
\text { uyumlu hale getirilmelidir. }\end{array}$ & $\begin{array}{l}1 \\
2 \\
3 \\
4 \\
5\end{array}$ & $\begin{array}{c}11,1 \\
9,5 \\
9,5 \\
30,2 \\
39,7\end{array}$ & 3,77 & 1,361 \\
\hline $\begin{array}{l}\text { Bağımsız denetim ile ilgili birçok düzenleme } \\
\text { yetkisinin Bakanlar Kuruluna bırakılması, } \\
\text { denetimi olumsuz etkiler. }\end{array}$ & $\begin{array}{l}1 \\
2 \\
3 \\
4 \\
5\end{array}$ & $\begin{array}{c}9,5 \\
9,5 \\
25,4 \\
39,7 \\
15,9\end{array}$ & 3,42 & 1,160 \\
\hline Denetim ücretlerine, bir standart getirilmelidir. & $\begin{array}{l}1 \\
2 \\
3 \\
4 \\
5\end{array}$ & $\begin{array}{c}11,1 \\
4,8 \\
7,9 \\
27,0 \\
49,2\end{array}$ & 3,98 & 1,337 \\
\hline $\begin{array}{l}\text { Denetçilerin denetim ücretleri, oluşturulacak } \\
\text { ortak bir havuzdan ödenmesi denetim kalitesini } \\
\text { olumlu etkileyecektir. }\end{array}$ & $\begin{array}{l}1 \\
2 \\
3 \\
4 \\
5\end{array}$ & $\begin{array}{l}17,5 \\
12,7 \\
12,7 \\
28,6 \\
28,6\end{array}$ & 3,38 & 1,463 \\
\hline $\begin{array}{l}\text { Denetçilere, Maliye Müfettişlerince düzenlenen } \\
\text { vergi inceleme raporlarını ve UYAP' ta yer alan } \\
\text { ticari dava bilgilerini görüntüleme yetkisi } \\
\text { verilmelidir. }\end{array}$ & $\begin{array}{l}1 \\
2 \\
3 \\
4 \\
5\end{array}$ & $\begin{array}{c}9,5 \\
11,1 \\
12,7 \\
27,0 \\
39,7\end{array}$ & 3,76 & 1,340 \\
\hline $\begin{array}{l}\text { Denetlenen işletmelerin yöneticilerinin } \\
\text { denetleme konusunda denetçileri } \\
\text { etkilememeleri için yasal düzenleme } \\
\text { yapılmalıdır. }\end{array}$ & $\begin{array}{l}1 \\
2 \\
3 \\
4 \\
5\end{array}$ & $\begin{array}{c}7,9 \\
9,5 \\
3,2 \\
36,5 \\
42,9\end{array}$ & 3,96 & 1,256 \\
\hline
\end{tabular}

Bağımsız Denetçi Ve Denetim Kuruluşlarının Kalitesini Artırmasına Yönelik Öneriler

Bağımsız denetimde kalitenin artırılması amacıyla hem bağımsız denetçi hem de bağımsız denetim kuruluşları ile ilgili 6 önerme kullanılmışır. Analiz yapılırken yüzde, ortalama ve standart sapma değerleri temel alınmıştır. Bu önermeler ve analizler Tablo 14'te verilmiştir. 
S.Elden Ürgüp-R.M. Bașar Bağımsız Denetime İlisskin Düzenlemeler...

Tablo 14. Bağımsız Denetçi ve Denetim Kuruluşlarının Kalitesini Artırmasına Yönelik Öneriler

\begin{tabular}{|c|c|c|c|c|}
\hline & & $\%$ & Ortalama & $\begin{array}{c}\text { Standart } \\
\text { Sapma }\end{array}$ \\
\hline $\begin{array}{l}\text { Denetimin, denetim firması aracıllı̆ı ile } \\
\text { yapılması denetim kalitesini arttırır. }\end{array}$ & $\begin{array}{l}1 \\
2 \\
3 \\
4 \\
5\end{array}$ & $\begin{array}{l}7,9 \\
11,1 \\
11,1 \\
23,8 \\
46,0\end{array}$ & 3,88 & 1,321 \\
\hline $\begin{array}{l}\text { Bağımsız denetçilik mesleki sorumluluk sigorta } \\
\text { primleri, oluşturulacak ortak bir fonda } \\
\text { toplanması, bağımsız denetimde otokontrol } \\
\text { sistemini oluşturacaktır. }\end{array}$ & $\begin{array}{l}1 \\
2 \\
3 \\
4 \\
5\end{array}$ & $\begin{array}{c}7,9 \\
14,3 \\
19,0 \\
49,2 \\
9,5\end{array}$ & 3,38 & 1,098 \\
\hline $\begin{array}{l}\text { Denetimde, denetim kuruluşlarının } \\
\text { tekelleşmesinin önüne geçecek bir yapı } \\
\text { oluşturulmalıdır. }\end{array}$ & $\begin{array}{l}1 \\
2 \\
3 \\
4 \\
5\end{array}$ & $\begin{array}{r}14,3 \\
1,6 \\
1,6 \\
38,1 \\
44,4\end{array}$ & 3,96 & 1,355 \\
\hline $\begin{array}{l}\text { Denetim kuruluşlarına denetim yetkisinin, } \\
\text { sektörler bazında verilmesi denetimde etkinliği } \\
\text { artırır. }\end{array}$ & $\begin{array}{l}1 \\
2 \\
3 \\
4 \\
5\end{array}$ & $\begin{array}{l}11,1 \\
25,4 \\
27,0 \\
25,4 \\
11,1\end{array}$ & 3,00 & 1,191 \\
\hline $\begin{array}{l}\text { Verilen denetim sertifikaların yurtdışındaki } \\
\text { sertifikasyonlarla uyumlu hale getirilmesi, } \\
\text { bağımsız denetim mesleğini etkin ve itibarlı } \\
\text { hale getirecektir. }\end{array}$ & $\begin{array}{l}1 \\
2 \\
3 \\
4 \\
5\end{array}$ & $\begin{array}{l}6,3 \\
9,5 \\
11,1 \\
39,7 \\
33,3\end{array}$ & 3,84 & 1,180 \\
\hline $\begin{array}{l}\text { Denetçilerin denetim ücretleri, oluşturulacak } \\
\text { ortak bir havuzdan ödenmesi denetim kalitesini } \\
\text { olumlu etkileyecektir. }\end{array}$ & $\begin{array}{l}1 \\
2 \\
3 \\
4 \\
5\end{array}$ & $\begin{array}{l}17,5 \\
12,7 \\
12,7 \\
28,6 \\
28,6\end{array}$ & 3,38 & 1,463 \\
\hline
\end{tabular}


Tablo 15. Ki-Kare Test Tablosu

\begin{tabular}{c|c|c|c|c|c|c}
\hline & $\begin{array}{c}\text { Önerme } \\
\mathbf{1}\end{array}$ & $\begin{array}{c}\text { Önerme } \\
\mathbf{2}\end{array}$ & $\begin{array}{c}\text { Önerme } \\
\mathbf{3}\end{array}$ & $\begin{array}{c}\text { Önerme } \\
\mathbf{4}\end{array}$ & $\begin{array}{c}\text { Önerme } \\
\mathbf{5}\end{array}$ & $\begin{array}{c}\text { Önerme } \\
\mathbf{6}\end{array}$ \\
\hline $\begin{array}{c}\mathrm{Ki}- \\
\text { Kare }\end{array}$ & $31,365^{\mathrm{a}}$ & $35,968^{\mathrm{a}}$ & $51,524^{\mathrm{a}}$ & $8,349^{\mathrm{a}}$ & $29,619^{\mathrm{a}}$ & $8,190^{\mathrm{a}}$ \\
\hline $\mathrm{df}$ & 4 & 4 & 4 & 4 & 4 & 4 \\
\hline $\mathrm{p}$ &, 000 &, 000 &, 000 &, 080 &, 000 &, 085 \\
\hline
\end{tabular}

Tablo 15'de bağımsız denetçi ve bağımsız denetim kuruluşlarının denetim kalitesini artırmalarına yönelik verilen önermelerin aritmetik ortalamasına ve standart sapmasına bakıldığında aritmetik ortalamanın 3 ile 4 arasında olması katılımcıların verilen önermelere karşı kararsız kaldıklarını veya katılıyor olduklarını göstermektedir. Anlamlılık değerlerinin ise önerme $1,2,3$ ve 5 'te $\mathrm{p}=0,00$ olduğu görülmekte ve anlamlı farklılık olmasından dolayı geliştirilen bu önermelerin bağımsız denetçi ve denetim kuruluşlarının kalitesini artıracağ 1 düşünülmektedir. Fakat önerme 4 ve 6 'da p değeri 0,05 'ten büyüktür ve anlamlı farklılık yoktur. Bu durumda da verilen önermelerin bağımsız denetçi ve denetim kuruluşlarının kalitesini artırmayacağı görüşü olduğu söylenebilir.

\section{SONUÇ VE ÖNERILER}

$\mathrm{Bu}$ çalışmada, TR 72 bölgesinde faaliyet gösteren bağımsız denetim kuruluşlarına bağlı bağımsız denetçilerin bağımsız denetime ilişkin yapılan düzenlemelerin ve bu düzenlemelerin etkilerinin ortaya konulması amaçlanmıştır. $\mathrm{Bu}$ açıdan ilk önce yapılan yasal düzenlemelerin hazırlanan denetim raporlarına etkisi tespit edilmiş ve bu düzenlemelerle birlikte denetim raporlarına duyulan güvenin arttığı sonucuna ulaşılmıştır.

Araştırmanın bir bulgusuna göre, bağımsız denetçilerin denetim sürecinde karşılaştıkları en önemli 3 sorunu sıralarken; birinci sırada \%16,66 oranla "Yapılan denetim işleminin kapsamının işletme yönetimi tarafından bilinmemesi" sorunu yer almaktadır. İkinci sıray1 \%12,87 oran ile "Denetim firmaları arasında yaşanan rekabet" sorunu yer alırken üçüncü sırayı 3 sorun birlikte paylaşmaktadır. Bunlar; "Denetime ilişkin düzenlemelerin yetersizliği, Mesleki eğitim ve yeterliliğe gereken önemin verilmemesi, Mevzuat karmaşası"'dır. Denetim faaliyetlerinin yürütüldüğü sırada bağımsız denetimin kapsamı ve firmalar arası yaşanan rekabetler en önemli sorunlar olarak ortaya çıkmıştır. Karmaşık ve fazla mevzuatın bulunması ve mesleki açıdan verilen eğitimlerin yetersizliği diğer önemli sorunlardır.

Araştırmanın bir diğer bulgusuna göre, bağımsız denetime dair yeterli bilgiye sahip olmayan ve gerekli önemi vermeyen denetlenen işletmelerin aynı zamanda 


\section{S.Elden Ürgüp-R.M. Bașar Bă̆ımsız Denetime İliskin Düzenlemeler...}

bağımsız denetim maliyetlerini de yüksek bulduğu görülmüştür. Bağımsız denetime tabi firmaların bağımsız denetime dair bilgi seviyeleri ile denetime verdikleri önem arasındaki ilişki anlamlıdır. Böylece bağımsız denetime tabi işletmelerin bilgi seviyelerinin yetersiz olması sonucunda bağımsız denetime yeterli önemi de vermedikleri söylenebilir.

Araştırmanın bir diğer önemli bulgusuna göre, denetim şirketlerinde tekelleşmenin varolduğu görülmektedir. Ayrıca anlamlı bir farklılık olduğundan denetim yetkisinin sektör bazlı verilmesinin denetimde etkinliği artıracağı ve dolayısıyla denetim kalitesini olumlu yönde etkileyeceği ve bu kalite ile tekelleşmenin önüne geçilebileceği söylenebilir.

Araştırmada, yasal düzenlemelerin yapılması ile birlikte bağımsız denetim kuruluşları tarafından hazırlanan denetim raporları arasında anlamlı bir ilişki olduğu sonucuna ulaşılmıştır. Yani denetçilerin yasal düzenlemeler çerçevesinde KGK'nın denetim faaliyetlerini yürütmesi gerektiğinin düşünüldüğü, hazırlanan denetim raporlarının güvenilir ve şeffaf olduğu düşüncesinin var olduğu söylenebilir.

Son olarak araştırmada, bağımsız denetçi ve bağımsız denetim kuruluşlarının denetim kalitesini artırmalarına yönelik verilen önermelerde anlamlı farklılık olduğu görülmektedir. Bundan dolayı geliştirilen bu önermelerin bağımsız denetçi ve denetim kuruluşlarının kalitesini artıracağı düşünülmektedir. Bazı önermelerde ise, anlamlı farkl1l1k yoktur. Bu durumda da verilen önermelerin bağımsız denetçi ve denetim kuruluşlarının kalitesini artırmayacağı görüşü olduğu söylenebilir.

Bu noktayla birlikte, bu çalışmanın bulguları dikkate alındığında, Türkiye'de denetlenen işletmelerin bağımsız denetime gereken önemi vermediği, işletmelerin TMS, TFRS ve denetim standartları hakkında yeterli bilgiye sahip olmadıkları ve denetim kapsamının işletme yönetimi tarafından bilinmediği görülmektedir. $\mathrm{Bu}$ eksiklikleri giderebilmek adına aşağıdaki noktalar araştırmacılara ve konuyla ilgili karar mekanizmalarında yer alan yetkililere öneri olarak sunulmaktadır:

- $\quad$ Etkin, verimli ve kaliteli bir denetim süreci için denetçilere düzenli ve sistemli bir şekilde gerekli tüm eğitimler verilebilir. Ayrıca Türkiye'de kurulan denetim firmalarının yurt dışında da faaliyet gösterebilmeleri için teknik destek ve teşviklerde bulunulabilir.

- Denetim kuruluşlarının tekelleşmesinin önüne geçilmesi ve bu tekelleşmeyi engelleyici bir yapının oluşturulması adına yasal düzenlemeler ile önlemler alınabilir. 
- Bağımsız denetçileri tek çatı altında toplayarak, bağımsız denetim ile ilgili düzenleme yapma yetkisi bulunan diğer kurumların da olmasıyla oluşan mevzuat karmaşasına son verilebilir. Böylece tek bir düzene bağlı bağımsız denetimin uygulanmasıyla sürecin daha sağlıklı ilerlemesi mümkün olacaktır.

- Denetim faaliyet sürecinde ortaya çıkan mevzuat karmaşıklığının önüne geçilmelidir. TMS, TFRS ve Vergi Mevzuatı acil bir şekilde uyumlu hale getirilmelidir.

- İşs sahiplerine bağımsız denetime tabi olmasının önem ve faydalarının anlatılması, denetime tabi işletmelerin de yetkili personelinin TFRS ve denetim konularında bilgilendirici eğitimler alınabilir. Bu sayede denetim kalitesini olumlu yönde etkileyebilecektir.

- Araştırmanın bulguları sadece TR 72 bölgesinde faaliyet gösteren bağımsız denetim kuruluşlarına bağlı bağımsız denetçilerin görüşleri ile sınırlıdır. Araştırmacılar tarafindan farklı bölgelerde faaliyette bulunan bağımsız denetçilere yönelik daha kapsamlı çalışmalarla konu farklı değişkenler açısından da ele alınarak literatüre daha kapsamlı bulgular kazandırılabilir.

\section{KAYNAKÇA}

Akdoğan, H. ve Yazar Bozkurt, B. (2012). Yeni Türk Ticaret Kanunu'nun denetim alanında getirdiği yenilikler. Hukuk ve İktisat Araştırmaları Dergisi, 4(2), 21-30.

Akyüz, F. ve Kestane, A. (2020). Yasal mevzuat ışığında denetçi bağımsızlığı. IBAD Sosyal Bilimler Dergisi, 6, 184-203.

Aydın, Y. ve Deniz, G. (2018). 2013-2017 dönemlerinde Türkiye'de bağımsız denetçi ve bağımsız denetim kuruluşlarının durumu. Socia lSciences Studies Journal, 4(20), 2483-2494.

Bezirci, M. ve Karasioğlu, F. (2011). Türkiye'de denetimin tarihsel gelişimi. Selçuk Üniversitesi IIBF Sosyal ve Ekonomik Araştırmalar Dergisi, 11(21). 572-592.

Bulut, E. (2015). Türkiye'de bağımsız denetimin kapsamı ve sınırları. Gümrük ve Ticaret Dergisi, 6, 60-73.

Çelik, Ü. (2012). Eski Türk Ticaret Kanunu, Sermaye Piyasası Kanunu ve Yeni Türk Ticaret Kanunu'nun bağımsız denetim yönünden incelenmesi, Yüksek Lisans Tezi, Marmara Üniversitesi.

Demir, M., Çiçekay, H. Arslan, Ö., ve Arslan, E. (2016). Muhasebe meslek mensuplarının bağımsız denetçilik mesleği hakkındaki düşünceleri: Van 
S.Elden Ürgüp-R.M. Başar $\quad$ Bağımsız Denetime İlisskin Düzenlemeler...

ilinde bir araştırma. Cumhuriyet Üniversitesi İktisadi İdari Bilimler Dergisi, 17(1), 37-56.

Demirtaş Aydoğan, S. (2016). Türkiye'de Bağımsız Denetimin Yeni Türk Ticaret Kanunu Çerçevesinde Değerlendirilmesi. Uluslararası Yönetim İktisat ve İsletme Dergisi, ICAFR 16, 12(12).771-785.

Doğan, B. ve Hilal, E. (2019). Türkiye'de muhasebe denetimi, İksad Yayınları.

Enerji Piyasas1 Düzenleme Kurumu Resmi İnternet Sitesi. https://www.epdk.gov.tr/Detay/Icerik/1-1051/tarihce

Erdoğan, M. (2002). Muhasebe, denetim ve bağımsız denetimin gerekliliği, Doğuş Üniversitesi Dergisi, 5, 51-63.

Erol, M. ve Aslan M. (2017), Uluslararası muhasebe ve denetim standartlarının gelişmesi. Muhasebe ve Finans Tarihi Araştırmaları Dergisi, Ocak (12), 55-86.

Ertaş, A. (2018), Bağımsız denetim kapsamında Türkiye'de yapılan yasal düzenlemelerin bağımsız denetim üzerine etkileri, [Doktora Tezi], Afyon Kocatepe Üniversitesi.

Fırat, A. ve Şahin, M. (2012). Türkiye'de bağımsız denetimin gözetimi ve denetim faaliyetlerinin gelişimi ve tarihçesi. Muhasebe ve Denetim Dünyası e-Dergi, 1-10.

Güvemli, O. ve Özbirecikli, M. (2011). Türkiye'de bağımsız muhasebe denetiminin gelişim süreci 1990-2011. Muhasebe ve Finans Araştırmaları Dergisi, 146-180.

Kalayc1, Ş. (2010). SPSS uygulamalı çok değişkenli istatistik teknikleri (5. Bask1). Asil Yayın Dağıtım.

Karadeniz, Y. (2015). 6102 Sayılı TTK kapsamında Türkiye'de bağımsız denetim ve kurumsal yönetim uygulamalarının değerlendirilmesi: nitel bir araştırma. İ̧sletme Araştırmaları Dergisi, 7(4), 313-335.

Karakoç, M. (2013). Türk Ticaret Kanunu ile birlikte bağımsız denetimde meydana gelen gelişmeler. Muhasebe ve Finansman Dergisi, 59, 17-37.

Kaya, G. A. (2020). Muhasebe meslek mensuplarının bağımsız denetim konusundaki düşüncelerine ilişsin bir araştırma. Fırat Üniversitesi Sosyal Bilimler Dergisi, 30(2), 335-351. 
KGK Bağımsız Denetim Yönetmeliği, (26 Aralık 2012).

Özçelik, H., Şenol, H. ve Aktürk, A. (2014). Muhasebe meslek mensuplarının bağımsız denetim alanındaki güncel gelişmelere bakış açıları ve farkındalıkları üzerine bir araştırma. Muhasebe ve Finansman Dergisi, Nisan, 62, ss.55-71.

Özulucan, A. ve Keleş, D. ve Arslan, S. (2015). Muhasebe meslek mensuplarının 6102 sayılı türk ticaret kanunu'nda yer alan bağımsız denetim ile ilgili hususlar hakkındaki görüşlerine yönelik Ordu ilinde bir araştırma. Niğde Üniversitesi IIIBF Dergisi, 9(1), 25-42.

Sermaye Piyasasında Bağımsız Denetim Standartları Hakkında Tebliğ, Seri: X, No: 22.https://spk.gov.tr/Sayfa/Dosya/590

Ulusan, H. ve Eren, E. ve Köylü, Ç. (2012). 6102 Sayılı Yeni Türk Ticaret Kanunu'nun muhasebe ve denetim uygulamalarına getirdiği yenilikler üzerine bir araştırma. Muhasebe ve Finansman Dergisi, Temmuz, 55, 1133.

Uzay, Ş. ve Bayat, S. B. (2016). 6102 Sayılı Türk Ticaret Kanunu'nun bağımsız denetim alanında getirdiği yenilikler ve tartışmalı konular. Süleyman Demirel Üniversitesi İktisadi İdari Bilimler Fakültesi Dergisi, 21(5), 1503-1513.

Yünlü, M. (2020). Türkiye'deki muhasebe uygulamalarının tarihsel gelişimi ve günümüzdeki durumu. Muhasebe ve Finans Tarihi Araştırmalar Dergisi, Ocak,18, 180-192.

5411 Sayılı Bankacılık Kanunu, Kasım 1, 2005. https://www.mevzuat.gov.tr/MevzuatMetin/1.5.5411.pdf

6362 Sayılı Sermaye Piyasası Kanunu, Aralı 30, 2012. https://www.mevzuat.gov.tr/MevzuatMetin/1.5.6362.pdf

660 Sayılı Kamu Gözetimi Muhasebe ve Denetim Standartları Kurumunun Teşkilat ve Görevleri Hakkında Kanun Hükmünde Kararname, 26 Ekim 2011. 